Supporting Information

\title{
A Simple Mechanochromic Mechanophore Based on Aminothiomaleimide
}

Min Tan, Zhitao Hu, Yunkai Dai, Yanling Peng, Yecheng Zhou, Yi Shi, Yuanchao Li, ${ }^{*}$ and Yongming Chen*

School of Materials Science and Engineering, Key Laboratory for Polymeric Composite and Functional Materials of Ministry of Education, Research Center for Functional Biomaterials Engineering and Technology Guangdong, Sun Yat-Sen University, Guangzhou 510275, China

*Corresponding authors: 1iyuanchao@mail.sysu.edu.cn and chenym35@mail.sysu.edu.cn 


\section{General Experimental Details}

All reagents were purchased from commercial suppliers and used as received unless otherwise noted. Tetrahydrofuran (THF) was dried with sodium metal under reflux overnight and then was distilled for further use. Triethylamine (TEA) was dried with $\mathrm{KOH}$ and distilled prior to use. Methyl acrylate was passed through a short column of basic alumina to remove inhibitor. Copper wire was pretreated with hydrochloric acid (12 M) to remove oxide of its surface.

NMR spectra were recorded with Bruker AVANCE III $400 \mathrm{MHz}$ and Bruker AVANCE III HD $600 \mathrm{MHz}$ system. Molecular weight and molecular weight distribution of the polymers were measured by an Agilent Technologies 1260 Infinity containing a refractive index detector. THF was used as eluent at a flow rate of $1.0 \mathrm{~mL} / \mathrm{min}$ at $40{ }^{\circ} \mathrm{C}$. Poly(methyl methacrylate) (PMMA) standards were used for calibration. Polymer solution was pressed through $220 \mathrm{~nm}$ filter prior to injection. Electrospray ionization mass spectroscopy (ESI-MS) was performed using a LTQ Orbitrap Elite and an Orbitrap fusion lumos mass spectrometer (Thermo Scientific). Fluorescence spectra were obtained by Gangdong F380 spectrofluorometer with an excitation wavelength of $370 \mathrm{~nm}$. Ultraviolet-visible (UV-vis) spectra were recorded with a Thermo Evolution 201 spectrometer in transmittance mode.

Sonication experiments were performed using a Sonics VCX 500 ultrasonic processor equipped with a $13 \mathrm{~mm}$ diameter solid probe. Polymer solutions were placed in a three-armed Suslick cell and degassed by bubbling nitrogen for 30 min prior to sonication. The Suslick cell was kept in an ice-water bath through the sonication process, and the ultrasound pulse was set to $1 \mathrm{~s} \mathrm{ON} / 1 \mathrm{~s}$ OFF, with $30 \%$ amplitude $\left(19.3 \mathrm{~W} / \mathrm{cm}^{2}\right)$. Aliquots were removed from the cell at various sonication time intervals for SEC and fluorescence spectroscopy measurements. The sonication time indicates the total time of "ON". 


\section{Synthetic Details}

\section{Synthesis of 1-benzyl-3,4-dibromo-1 $H$-pyrrole-2,5-dione (2)}

Compound 2 was synthesized following a procedure described in the literature. ${ }^{1}$ Briefly, 2,3dibromomaleimide (1.33 g, $5.2 \mathrm{mmol})$, potassium carbonate $(0.87 \mathrm{~g}, 6.2 \mathrm{mmol})$ were dissolved with $25 \mathrm{~mL}$ acetone in a $50 \mathrm{~mL}$ round bottom flask, and then benzyl bromide $(0.75 \mathrm{~mL}, 6.3$ mmol) was added. The mixed solution was stirred at room temperature overnight. Ethyl acetate (EtOAc, $100 \mathrm{~mL}$ ) was added and the organic layer was washed with $200 \mathrm{~mL}$ saturated $\mathrm{NaCl}$ solution. The organic phase was dried over $\mathrm{Na}_{2} \mathrm{SO}_{4}$, filtered and concentrated under reduced pressure. The crude product was purified by column chromatography $\left(\mathrm{SiO}_{2}\right.$, hexane/EtOAc, 10:1) to provide the title compound as an off-white powder (1.17 g, $3.4 \mathrm{mmol}, 65 \%)$.

${ }^{1} \mathrm{H}-\mathrm{NMR}(600 \mathrm{MHz}, \mathrm{DMSO}-\mathrm{d} 6) \delta(\mathrm{ppm}): 4.66(\mathrm{~s}, 2 \mathrm{H}), 7.30(\mathrm{~m}, 5 \mathrm{H}) ;{ }^{13} \mathrm{C}-\mathrm{NMR}(151 \mathrm{MHz}$, DMSO-d6) $\delta$ (ppm): 42.32, 127.41, 127.52, 128.52, 129.34, 135.91, 164.19; HRMS (ESI, m/z) : $\left[\mathrm{M}+\mathrm{H}^{+}\right]$calcd for $\mathrm{C}_{11} \mathrm{H}_{7} \mathrm{Br}_{2} \mathrm{NO}_{2}$ 343.89163, found 343.89164 .

\section{Synthesis of 1-benzyl-3-bromo-4-((2-hydroxyethyl)amino)-1H-pyrrole-2,5-dione (3)}

Dibromomaleimide $2(0.95 \mathrm{~g}, 2.8 \mathrm{mmol})$, sodium carbonate $(0.73 \mathrm{~g}, 6.9 \mathrm{mmol})$ were dissolved with $20 \mathrm{~mL}$ tetrahydrofuran $(\mathrm{THF})$ in a $50 \mathrm{~mL}$ round bottom flask, and ethanolamine $(0.18 \mathrm{~g}$, $2.91 \mathrm{mmol}$ ) was gradually added to the solution under stirring. The reaction was allow to proceed at room temperature in the dark overnight. The solvent was evaporated under reduced pressure after filtration, the residue was dissolved with $100 \mathrm{~mL}$ EtOAc and then washed with $(2 \times 50 \mathrm{~mL})$. The aqueous phase was extracted with EtOAc, and all the organic phases were combined, dried over $\mathrm{Na}_{2} \mathrm{SO}_{4}$, filtered and concentrated under reduced pressure. The crude product was purified by column chromatography $\left(\mathrm{SiO}_{2}\right.$, hexane/EtOAc, 3:1) to provide compound $3(0.76 \mathrm{~g}, 84 \%)$. 
${ }^{1} \mathrm{H}-\mathrm{NMR}$ (600 MHz, DMSO-d6) $\delta$ (ppm): 3.55 (m, 2H), 3.58 (m, 2H), 4.58 (s, 2H), 7.23-7.33 (m, 5H), $7.82(\mathrm{br}, 1 \mathrm{H}) ;{ }^{13} \mathrm{C}-\mathrm{NMR}(151 \mathrm{MHz}, \mathrm{DMSO}-\mathrm{d} 6) \delta$ (ppm): 41.13, 44.59, 60.22, 127.26, 127.39, 128.56, 136.81, 144.34, 165.10, 167.30; HRMS (ESI, m/z): $\left[\mathrm{M}-\mathrm{H}^{+}\right]$calcd for $\mathrm{C}_{13} \mathrm{H}_{13} \mathrm{BrN}_{2} \mathrm{O}_{3} 323.00368$, found 323.00395.

\section{Synthesis of 1-benzyl-3-((2-hydroxyethyl)amino)-4-((2-hydroxyethyl)thio)-1H-pyrrole-2,5-}

dione (4)

Aminobromomaleimide 3 (0.76 g, $2.4 \mathrm{mmol})$ was dissolved with $10 \mathrm{~mL}$ dimethylformamide (DMF) in a $50 \mathrm{~mL}$ round bottom flask, followed by addition of $\mathrm{NaOH}(0.14 \mathrm{~g}, 3.5 \mathrm{mmol})$. The mixture was stirred for 5 minutes, and then $5 \mathrm{~mL}$ solution of 2-mercaptoethanol $(0.20 \mathrm{~g}, 2.6$ mmol) in DMF was added dropwise. Afterwards, the solution was heated up to $80{ }^{\circ} \mathrm{C}$ in an oil bath and allowed to react for 18 hours. The reaction mixture was concentrated under reduced pressure and $100 \mathrm{~mL}$ EtOAc was added. The organic solution was washed with saturated $\mathrm{NaCl}$ solution $(2 \times 50 \mathrm{~mL})$. The aqueous phase was extracted back with EtOAc. All the organic phases were combined, dried over $\mathrm{Na}_{2} \mathrm{SO}_{4}$, filtered and concentrated under reduced pressure. The crude product was purified by column chromatography $\left(\mathrm{SiO}_{2}\right.$, hexane/EtOAc, 1:2) to provide compound $4(0.15 \mathrm{~g}, 20 \%)$.

${ }^{1} \mathrm{H}-\mathrm{NMR}(600 \mathrm{MHz}, \mathrm{DMSO}-\mathrm{d} 6) \delta$ (ppm): 2.66 (t, 2H), 3.49 (q, 2H), 3.59 (q, 2H), 3.80 (q, 2H), $4.57(\mathrm{~s}, 2 \mathrm{H}), 4.72(\mathrm{t}, 1 \mathrm{H}), 4.84(\mathrm{t}, 1 \mathrm{H}), 7.22-7.33(\mathrm{~m}, 5 \mathrm{H}), 7.79(\mathrm{br}, 1 \mathrm{H}) ;{ }^{13} \mathrm{C}-\mathrm{NMR}(151 \mathrm{MHz}$ DMSO-d6) $\delta$ (ppm): 37.84, 40.85, 44.98, 54.86, 59.75, 60.12, 127.17, 127.27, 128.50, 136.98, 149.33, 165.51, 170.87; HRMS (ESI, m/z) : [M - $\left.\mathrm{H}^{+}\right]$calcd for $\mathrm{C}_{15} \mathrm{H}_{18} \mathrm{~N}_{2} \mathrm{O}_{4} \mathrm{~S} 321.0915$, found 321.0916. 
Synthesis of 2-((1-benzyl-4-((2-((2-bromo-2-methylpropanoyl)oxy)ethyl)amino)-2,5-dioxo-

\section{2,5-dihydro-1 H-pyrrol-3-yl)thio)ethyl 2-bromo-2-methylpropanoate (5)}

Aminothiomaleimide 4 (146 mg, $0.46 \mathrm{mmol})$ and dry triethylamine $\left(\mathrm{Et}_{3} \mathrm{~N}, 0.19 \mathrm{~mL}, 1.36 \mathrm{mmol}\right)$ were dissolved with $5 \mathrm{~mL}$ dry THF in a $25 \mathrm{~mL}$ pre-dried round bottom flask. The flask was then placed in an ice-water bath, and a solution of $\alpha$-bromoisobutyryl bromide $(0.17 \mathrm{~mL}, 1.37$ mmol) in $5 \mathrm{~mL}$ dry THF was added dropwise under stirring. After the addition was finished, the solution was allowed warm to room temperature and left to stir overnight. The solution was concentrated under reduced pressure, and the residue was dissolved in $100 \mathrm{~mL}$ dichloromethane (DCM). The solution was then washed with saturated sodium bicarbonate $(100 \mathrm{~mL})$, dried over $\mathrm{Na}_{2} \mathrm{SO}_{4}$, filtered and concentrated under reduced pressure. The crude product was purified by column chromatography $\left(\mathrm{SiO}_{2}\right.$, hexane/DCM, elution gradient $50-90 \%$ DCM) to provide compound $\mathbf{5}$ as a yellow oil liquid (208 $\mathrm{mg}, 75 \%)$.

${ }^{1} \mathrm{H}-\mathrm{NMR}\left(600 \mathrm{MHz}, \mathrm{CDCl}_{3}\right) \delta(\mathrm{ppm}): 1.90(\mathrm{~s}, 3 \mathrm{H}), 1.91$ (s, 3H), $3.00(\mathrm{t}, 2 \mathrm{H}), 4.14(\mathrm{q}, 2 \mathrm{H}), 4.34$ $(\mathrm{t}, 2 \mathrm{H}), 4.38(\mathrm{t}, 2 \mathrm{H}), 4.65(\mathrm{~s}, 2 \mathrm{H})$, 5.94(br, $1 \mathrm{H}), 7.26-7.33(\mathrm{~m}, 5 \mathrm{H}) .{ }^{13} \mathrm{C}-\mathrm{NMR}\left(151 \mathrm{MHz}, \mathrm{CDCl}_{3}\right)$ $\delta(\mathrm{ppm}) 30.66,30.81,33.70,42.11,42.28,55.46,55.71,64.27,64.68,127.92,128.60,128.77$, 136.30, 148.35, 165.66, 170.71, 171.52, 171.66; HRMS (ESI, m/z) : $\left[\mathrm{M}+\mathrm{H}^{+}\right]$calcd for $\mathrm{C}_{23} \mathrm{H}_{28} \mathrm{Br}_{2} \mathrm{~N}_{2} \mathrm{O}_{6} \mathrm{~S}$ 619.01076, found 619.01112.

\section{Synthesis of 1-benzyl-3-(butylthio)-4-((2-hydroxyethyl)amino)-1H-pyrrole-2,5-dione (6)}

Aminobromomaleimide $3(0.43 \mathrm{~g}, 1.3 \mathrm{mmol})$ was dissolved with $5 \mathrm{~mL}$ DMF in a $25 \mathrm{~mL}$ round bottom flask, followed by addition of $\mathrm{NaOH}(0.08 \mathrm{~g}, 2.0 \mathrm{mmol})$. The mixture was stirred for 5 minutes, and then $5 \mathrm{~mL}$ solution of 1-butanethiol $(0.143 \mathrm{~g}, 1.6 \mathrm{mmol})$ in DMF was added dropwise. Afterwards, the solution was heated up to $80^{\circ} \mathrm{C}$ in an oil bath and allowed to react for 18 hours. The reaction mixture was concentrated under reduced pressure and $50 \mathrm{~mL}$ EtOAc 
was added. The organic solution was washed with saturated $\mathrm{NaCl}$ solution $(3 \times 50 \mathrm{~mL})$ and dried over $\mathrm{Na}_{2} \mathrm{SO}_{4}$, filtered and concentrated under reduced pressure. The crude product was purified by column chromatography $\left(\mathrm{SiO}_{2}\right.$, hexane/EtOAc, $\left.1: 3\right)$ to provide compound $6(0.13$ $\mathrm{g}, 29 \%)$.

${ }^{1} \mathrm{H}-\mathrm{NMR}\left(600 \mathrm{MHz}, \mathrm{CDCl}_{3}\right) \delta(\mathrm{ppm}): 0.89(\mathrm{t}, 3 \mathrm{H}), 1.39(\mathrm{~m}, 2 \mathrm{H}), 1.54(\mathrm{~m}, 2 \mathrm{H}), 2.68(\mathrm{t}, 2 \mathrm{H})$, $3.83(\mathrm{t}, 2 \mathrm{H}), 3.95(\mathrm{q}, 2 \mathrm{H}), 4.65(\mathrm{~s}, 2 \mathrm{H}), 6.00(\mathrm{t}, 1 \mathrm{H}), 7.23-7.35(\mathrm{~m}, 5 \mathrm{H}) ;{ }^{13} \mathrm{C}-\mathrm{NMR}(151 \mathrm{MHz}$ $\left.\mathrm{CDCl}_{3}\right) \delta(\mathrm{ppm}): 13.80,21.97,31.98,35.69,41.99,45.27,61.55,127.84,128.55,128.73$, 136.58, 148.21, 166.31, 171.21; HRMS (ESI, m/z) : $\left[\mathrm{M}+\mathrm{H}^{+}\right]$calcd for $\mathrm{C}_{17} \mathrm{H}_{22} \mathrm{~N}_{2} \mathrm{O}_{3} \mathrm{~S}$ 335.14239 , found 335.14188 .

Synthesis of 2-((1-benzyl-4-(butylthio)-2,5-dioxo-2,5-dihydro-1H-pyrrol-3yl)amino)ethyl 2-bromo-2-methylpropanoate (7)

Aminothiomaleimide $6(127 \mathrm{mg}, 0.38 \mathrm{mmol})$ and dry $\mathrm{Et}_{3} \mathrm{~N}(80 \mu \mathrm{L}, 0.57 \mathrm{mmol})$ were dissolved with $5 \mathrm{~mL}$ dry THF in a $25 \mathrm{~mL}$ pre-dried round bottom flask. The flask was then placed in an ice-water bath, and a solution of $\alpha$-bromoisobutyryl bromide ( $80 \mu \mathrm{L}, 0.65 \mathrm{mmol}$ ) in $5 \mathrm{~mL}$ dry THF was added dropwise under stirring. After the addition was finished, the solution was allowed warm to room temperature and left to stir overnight. The solution was concentrated under reduced pressure, and the residue was dissolved in $50 \mathrm{~mL}$ DCM. The solution was then washed with saturated sodium bicarbonate $(50 \mathrm{~mL})$, dried over $\mathrm{Na}_{2} \mathrm{SO}_{4}$, filtered and concentrated under reduced pressure. The crude product was purified by column chromatography $\left(\mathrm{SiO}_{2}\right.$, petroleum ether/DCM, 1:1) to provide compound 7 as a yellow powder $(160 \mathrm{mg}, 87 \%)$.

${ }^{1} \mathrm{H}-\mathrm{NMR}\left(600 \mathrm{MHz}, \mathrm{CDCl}_{3}\right) \delta(\mathrm{ppm}): 0.90(\mathrm{t}, 3 \mathrm{H}), 1.40(\mathrm{~m}, 2 \mathrm{H}), 1.55(\mathrm{~m}, 2 \mathrm{H}), 1.92(\mathrm{~s}, 6 \mathrm{H})$, $2.72(\mathrm{t}, 2 \mathrm{H}), 4.14(\mathrm{q}, 2 \mathrm{H}), 4.37(\mathrm{t}, 2 \mathrm{H}), 4.65(\mathrm{~s}, 2 \mathrm{H}), 5.78(\mathrm{t}, 1 \mathrm{H}), 7.23-7.37(\mathrm{~m}, 5 \mathrm{H}) ;{ }^{13} \mathrm{C}-\mathrm{NMR}$ $\left(151 \mathrm{MHz}, \mathrm{CDCl}_{3}\right) \delta(\mathrm{ppm}): 13.79,21.97,30.69,32.04,35.52,42.03,42.08,55.49,64.46$, 
127.87, 128.57, 128.75, 136.51, 147.68, 166.08, 170.90, 171.69; HRMS (ESI, m/z) : [M+ $\left.\mathrm{H}^{+}\right]$

calcd for $\mathrm{C}_{21} \mathrm{H}_{27} \mathrm{BrN}_{2} \mathrm{O}_{4} \mathrm{~S} 483.09477$, found 483.09411 .

\section{Synthesis of ATM-PMA and the control polymer}

A stock solution of $16 \mu \mathrm{L}$ tris[2-(dimethylamino)ethyl]amine $\left(\mathrm{Me}_{6} \mathrm{TREN}, 0.06 \mathrm{mmol}\right)$ and 5.6 $\mathrm{mg} \mathrm{CuBr} 2(0.025 \mathrm{mmol})$ in $1.0 \mathrm{~mL}$ dry DMSO was prepared in advance. ATM-PMA and the control polymer were synthesized in a similar manner. As an example, a typical procedure for synthesizing ATM-PMA is given. To a $25 \mathrm{~mL}$ Schlenk flask, compound 5 (9.0 mg, 0.015 mmol), methyl acrylate (MA, $3.0 \mathrm{~mL}, 33.0 \mathrm{mmol}), 100 \mu \mathrm{L}$ of the stock solution and $1.0 \mathrm{~mL}$ dry DMSO were added. The mixture was then degassed by three cycles of freeze-pump-thaw followed by adding a stir bar wrapped with a pretreated copper wire $(2 \mathrm{~cm})$ under nitrogen atmosphere. Then another cycle of freeze-pump-thaw was carried out. After being sealed, the Schlenk flask was immersed in an oil bath at $30{ }^{\circ} \mathrm{C}$. The polymerization was terminated after $45 \mathrm{~min}$ by exposing to the air in liquid nitrogen. The reaction mixture was diluted with $20 \mathrm{~mL}$ THF and passed through a neutral alumina column to remove the copper catalysts. The filtrated solution was concentrated and precipitated in cold methanol. The recovered polymer was dried in a vacuum oven at $40{ }^{\circ} \mathrm{C}$, yielding a bright yellow solid (654 mg, 46\%).

\section{Synthesis of polymer containing aminomaleimide moiety at chain end (reference polymer)}

Scheme S1. Synthesis of the reference polymer. 

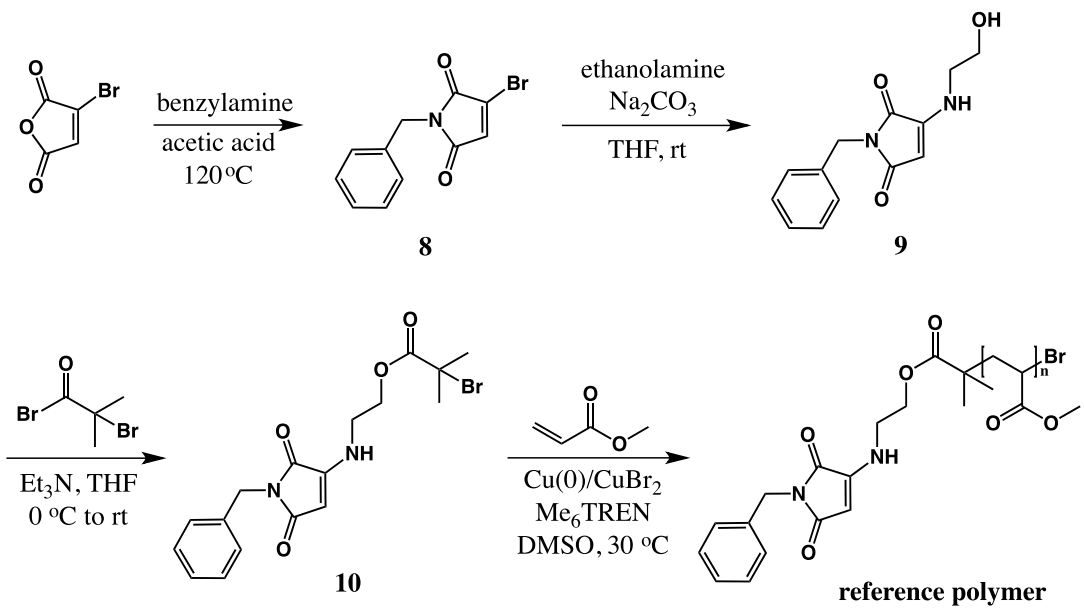

Synthesis of 1-benzyl-3-bromo-1H-pyrrole-2,5-dione (8). Bromomaleic anhydride (1 g, $5.7 \mathrm{mmol})$ was dissolved with $20 \mathrm{~mL}$ acetic acid in a $50 \mathrm{~mL}$ round bottom flask and then benzylamine $(0.65 \mathrm{~g}, 6.0 \mathrm{mmol})$ was added. The solution was heated to $120{ }^{\circ} \mathrm{C}$ in an oil bath and left to stir for 8 hours. Afterwards, the solution was cooled to room temperature, and acetic acid was evaporated under reduced pressure. The residue was dissolved with $50 \mathrm{~mL}$ DCM and washed with saturated $\mathrm{NaCl}$ solution $(3 \times 30 \mathrm{~mL})$. The organic layer was dried over $\mathrm{Na}_{2} \mathrm{SO}_{4}$, filtered and concentrated under reduced pressure. The crude product was purified by column chromatography $\left(\mathrm{SiO}_{2}\right.$, hexane/EtOAc, 10:1) to afford the title compound as a light brown solid (1.05 g, 67\%).

${ }^{1} \mathrm{H}-\mathrm{NMR}\left(600 \mathrm{MHz}, \mathrm{DMSO}-\mathrm{d}_{6}\right) \delta(\mathrm{ppm}): 4.63(\mathrm{~s}, 2 \mathrm{H}), 7.26-7.33$ (m, 5H), 7.50 (s, 1H); ${ }^{13} \mathrm{C}-\mathrm{NMR}(151 \mathrm{MHz}, \mathrm{DMSO}-\mathrm{d} 6) \delta$ (ppm): 41.46, 127.32, 127.49, 128.57, 130.52, 132.77, 136.28, 165.50, 168.75; HRMS (ESI, m/z) : [M+ $\left.\mathrm{H}^{+}\right]$ calcd for $\mathrm{C}_{11} \mathrm{H}_{8} \mathrm{BrNO}_{2} 265.98112$, found 265.98123.

Synthesis of 1-benzyl-3-((2-hydroxyethyl)amino)-1H-pyrrole-2,5-dione (9). 2-bromomaleimide $8(0.53 \mathrm{~g}, 2.0 \mathrm{mmol})$ and sodium carbonate $(0.53 \mathrm{~g}, 5.0$ mmol) were dissolved with $10 \mathrm{~mL}$ THF in a $25 \mathrm{~mL}$ round bottom flask. 
Subsequently $5 \mathrm{~mL}$ THF solution of ethanolamine $(0.13 \mathrm{~g}, 2.2 \mathrm{mmol})$ was added dropwise, and the solution was stirred overnight at room temperature in the dark. The reaction mixture was filtered and concentrated under reduced pressure. The residue was dissolved in $100 \mathrm{~mL}$ EtOAc and washed with saturated $\mathrm{NaCl}(2 \times$ $50 \mathrm{~mL})$. The aqueous phase was extract with ethyl acetate $(2 \times 100 \mathrm{~mL})$. All organic phases were combined, dried over $\mathrm{Na}_{2} \mathrm{SO}_{4}$, filtered and concentrated under reduced pressure. The crude product was purified by column chromatography $\left(\mathrm{SiO}_{2}\right.$, hexane/EtOAc, $\left.1: 1\right)$ to provide the title compound a luminous yellow powder (486 mg, 99\%).

${ }^{1} \mathrm{H}-\mathrm{NMR}\left(600 \mathrm{MHz}, \mathrm{DMSO}-\mathrm{d}_{6}\right) \delta(\mathrm{ppm}): 3.18(\mathrm{q}, 2 \mathrm{H}), 3.53(\mathrm{q}, 2 \mathrm{H}), 4.53(\mathrm{~s}$, 2H), $4.78(\mathrm{t}, 1 \mathrm{H}), 4.93(\mathrm{~s}, 1 \mathrm{H}), 7.21-7.32(\mathrm{~m}, 5 \mathrm{H}), 7.72(\mathrm{t}, 1 \mathrm{H}) ;{ }^{13} \mathrm{C}-\mathrm{NMR}(151$ MHz, DMSO-d6) $\delta$ (ppm): 40.05, 46.62, 58.67, 82.38, 127.15, 127.20, 128.51, 137.42, 150.80, 166.65, 171.61; HRMS (ESI, m/z) : $\left[\mathrm{M}+\mathrm{H}^{+}\right]$calcd for $\mathrm{C}_{13} \mathrm{H}_{14} \mathrm{~N}_{2} \mathrm{O}_{3} 247.10772$, found 247.10779.

Synthesis of 2-((1-benzyl-2,5-dioxo-2,5-dihydro-1H-pyrrol-3yl)amino)ethyl 2-bromo-2-methylpropanoate (10). Aminomaleimide 9 (492 $\mathrm{mg}, 2.0 \mathrm{mmol})$ and dry $\mathrm{Et}_{3} \mathrm{~N}(420 \mu \mathrm{L}, 3.0 \mathrm{mmol})$ were dissolved with $5 \mathrm{~mL}$ dry THF in a $25 \mathrm{~mL}$ pre-dried round bottom flask. The flask was then placed in an ice-water bath, and a solution of $\alpha$-bromoisobutyryl bromide $(370 \mu \mathrm{L}, 3.0 \mathrm{mmol})$ in $5 \mathrm{~mL}$ dry THF was added dropwise under stirring. After the addition was finished, the solution was allowed warm to room temperature and left to stir overnight. The solution was concentrated under reduced pressure, and the residue was dissolved in $50 \mathrm{~mL}$ DCM. The solution was then washed with saturated sodium bicarbonate $(50 \mathrm{~mL})$, dried over $\mathrm{Na}_{2} \mathrm{SO}_{4}$, filtered and concentrated under reduced pressure. The crude product was purified by column 
chromatography $\left(\mathrm{SiO}_{2}\right.$, petroleum ether/DCM, 1:3) to provide compound $\mathbf{1 0}$ as creamy solid (315 mg, 64\%).

${ }^{1} \mathrm{H}-\mathrm{NMR}$ (600 MHz, DMSO-d6) $\delta(\mathrm{ppm}): 1.86$ (s, 6H), 3.45 (q, 2H), 4.27 (t, 2H), $4.53(\mathrm{~s}, 2 \mathrm{H}), 5.05(\mathrm{~s}, 1 \mathrm{H}), 7.17-7.34(\mathrm{~m}, 5 \mathrm{H}), 7.87(\mathrm{t}, 1 \mathrm{H}) ;{ }^{13} \mathrm{C}-\mathrm{NMR}(151$ MHz, DMSO-d6) $\delta$ (ppm): 30.18, 40.04, 42.24, 57.06, 63.54, 83.32, 127.01, 127.17, 128.45, 137.31, 150.59, 166.59, 170.76, 171.53; HRMS (ESI, m/z) : [M $\left.+\mathrm{H}^{+}\right]$calcd for $\mathrm{C}_{17} \mathrm{H}_{19} \mathrm{BrN}_{2} \mathrm{O}_{4}$ 395.06010, found 395.05978.

Synthesis of the reference polymer. To a $25 \mathrm{~mL}$ Schlenk flask, compound $\mathbf{1 0}$ (8.0 mg, $0.02 \mathrm{mmol}$ ), methyl acrylate (MA, $4.0 \mathrm{~mL}, 33.0 \mathrm{mmol}$ ), $64 \mu \mathrm{L}$ $\mathrm{Me}_{6}$ TREN (0.024 mmol) and $3.5 \mathrm{~mL}$ dry DMSO were added. The mixture was then degassed by three cycles of freeze-pump-thaw followed by adding a stir bar wrapped with a pretreated copper wire $(2 \mathrm{~cm})$ under nitrogen atmosphere. Then another cycle of freeze-pump-thaw was carried out. After being sealed, the Schlenk flask was immersed in an oil bath at $30^{\circ} \mathrm{C}$. The polymerization was terminated after $120 \mathrm{~min}$ by exposing to the air in liquid nitrogen. The reaction mixture was diluted with $20 \mathrm{~mL}$ THF and passed through a neutral alumina column to remove the copper catalysts. The filtrated solution was concentrated and precipitated in cold methanol. The recovered polymer was dried in a vacuum oven at $40{ }^{\circ} \mathrm{C}$, yielding a bright yellow solid $(2.13 \mathrm{~g}, 56 \%)$.

\section{Analysis of Fluorescence Spectra}

Assuming that the fluorescence spectrum of the ATM-PMA solution after ultrasonication for 180 min corresponds to the final mechanochemical products of ATM and that the fluorescence spectra of the ATM-PMA solution after various ultrasonication times can 
be approximated as a linear combination of the contributions from ATM (peak at 550) and its mechanochemical products (peak at $\sim 476 \mathrm{~nm}$ ), the fluorescence spectra of the ATM-PMA solution upon ultrasonication can be expressed by the following equation:

$$
S_{t} \cong k_{1} S_{0}+k_{2} S_{180}
$$

where $S_{0}, S_{180}$, and $S_{\mathrm{t}}$ stand for the fluorescence spectra of the solution before ultrasonication, after $180 \mathrm{~min}$ of ultrasonication, and after ultrasonication for time $t, k_{1}$ and $k_{2}$ are the corresponding coefficients. According to the above equation, the sum of the emission intensities of ATM and its mechanochemical product is equal to that of ATM-PMA solution at any given emission wavelength. Therefore to calculate $k_{1}$ and $k_{2}$, we choose the emission peak wavelengths of $476 \mathrm{~nm}$ and $550 \mathrm{~nm}$ respectively and derive the following equations:

$$
\begin{aligned}
& k_{1} S_{0}(550)+k_{2} S_{180}(550) \cong S_{t}(550) \\
& k_{1} S_{0}(476)+k_{2} S_{180}(476) \cong S_{t}(476)
\end{aligned}
$$

where $S_{0}(550), S_{180}(550)$ and $S_{t}(550)$ are the respective emission intensities at $550 \mathrm{~nm}, S_{0}$ (476), $S_{180}(476)$ and $S_{t}(476)$ are the respective emission intensities at $476 \mathrm{~nm}$. By solving the equations, we can calculate $k_{1}$ and $k_{2}$ using the expressions as below:

$$
\begin{gathered}
k_{1}=\left(\frac{S_{t}(550)}{S_{180}(550)}-\frac{S_{t}(476)}{S_{180}(476)}\right) /\left(\frac{S_{0}(550)}{S_{180}(550)}-\frac{S_{0}(476)}{S_{180}(476)}\right) \\
k_{2}=\left(\frac{S_{t}(550)}{S_{0}(550)}-\frac{S_{t}(476)}{S_{0}(476)}\right) /\left(\frac{S_{180}(550)}{S_{0}(550)}-\frac{S_{180}(476)}{S_{0}(476)}\right)
\end{gathered}
$$




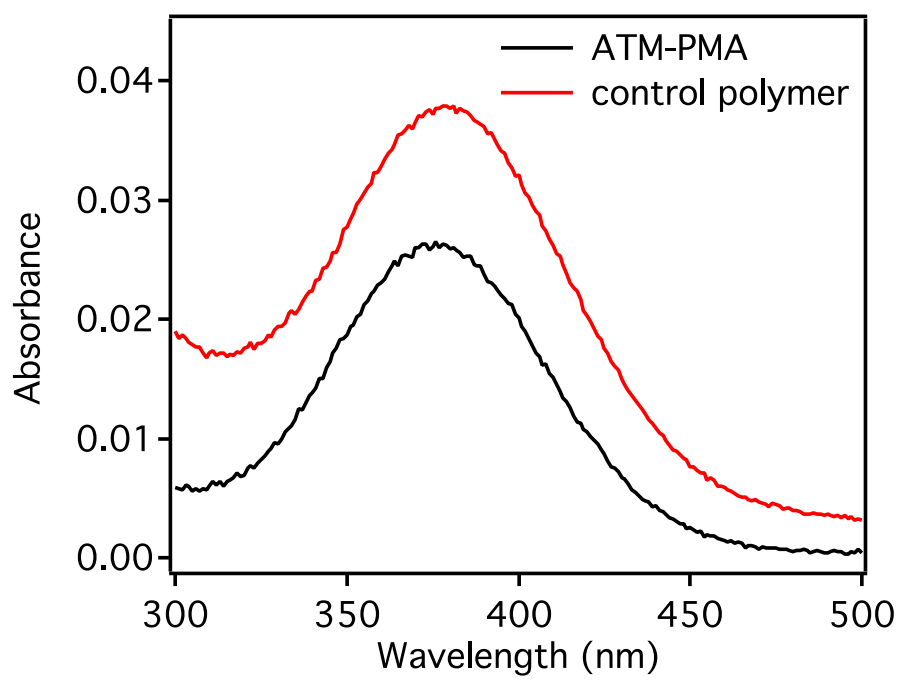

Figure S1. UV-vis spectra of ATM-PMA and the control polymer $(5.0 \mathrm{mg} / \mathrm{mL})$. 

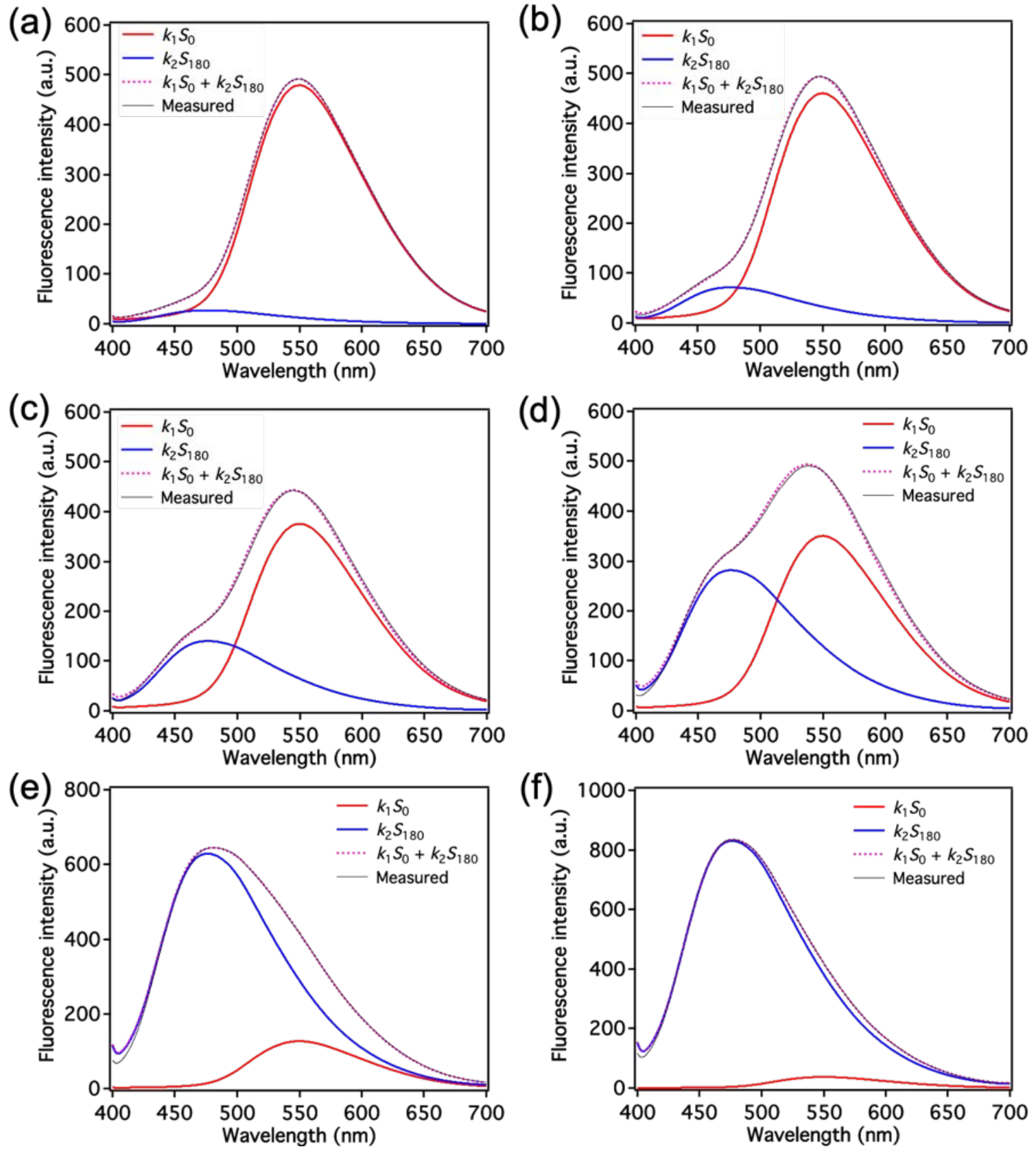

Figure S2. The measured fluorescence spectrum of the ATM-PMA solution after ultrasonication for a certain time as indicated can be approximated to the sum of $S_{0}$ and $S_{180}$ with calculated coefficients $k_{1}$ and $k_{2}$ : (a) $2 \mathrm{~min}, k_{1}=0.90$ and $k_{2}=0.03$; (b) $4 \mathrm{~min}, k_{1}=0.87$ and $k_{2}=0.09$; (c) $8 \mathrm{~min}, k_{1}=0.71$ and $k_{2}=0.17$; (d) $16 \mathrm{~min}, k_{1}=0.66$ and $k_{2}=0.34$; (e) 60 $\min , k_{1}=0.24$ and $k_{2}=0.75$; (f) $120 \min , k_{1}=0.07$ and $k_{2}=0.99$. 


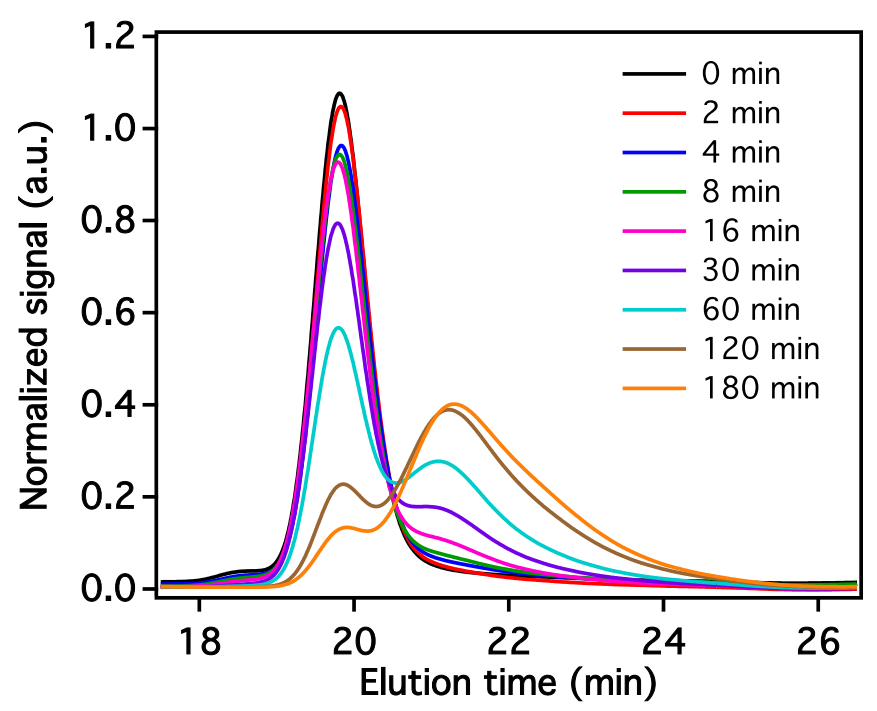

Figure S3. Representative SEC traces (refractive index signals) of a dilute solution of the control polymer $(5.0 \mathrm{mg} / \mathrm{mL})$ upon ultrasonication for different times.

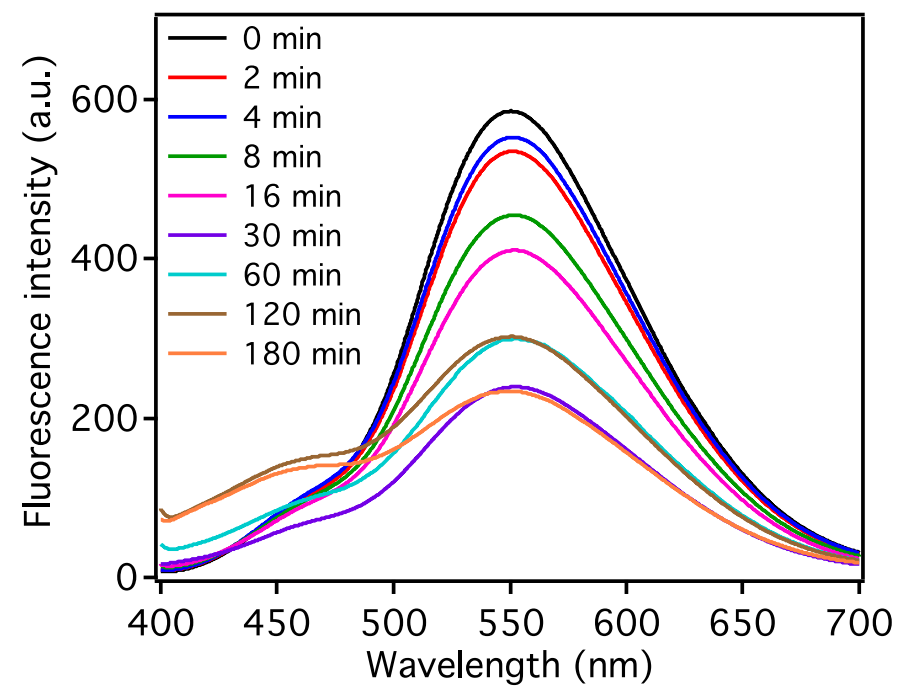

Figure S4. Representative fluorescence emission spectra of a dilute solution $(5.0 \mathrm{mg} / \mathrm{mL})$ of the control polymer upon ultrasonication for different times with excitation wavelength of 370 nm. Being different from ATM-PMA, the control polymer has an emission band around 476 $\mathrm{nm}$, and it changes slightly upon ultrasonication, which could be attributed to certain side reactions. 


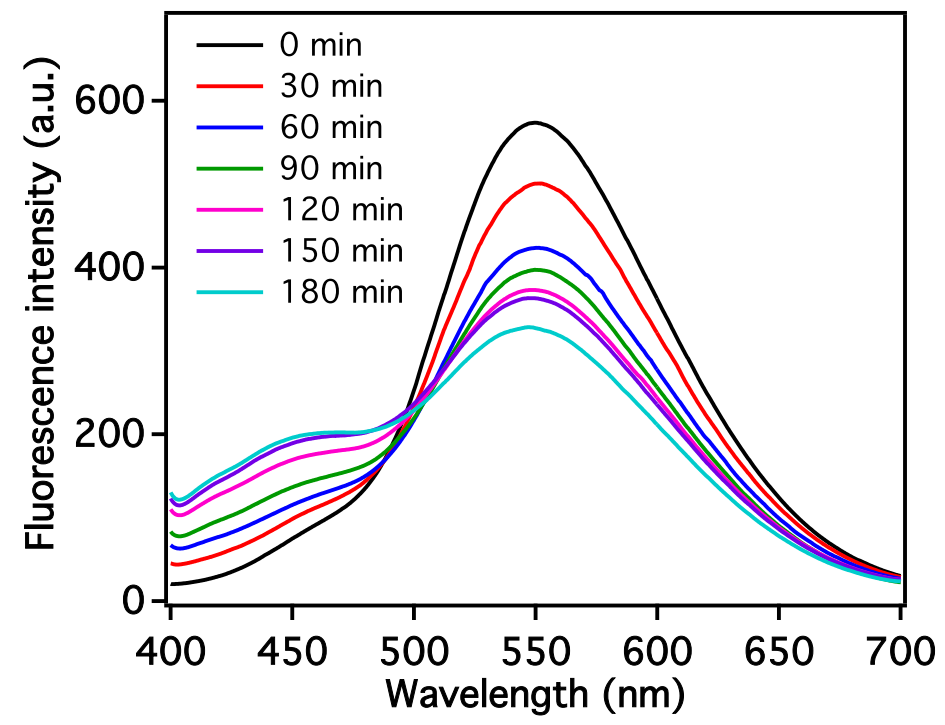

Figure S5. Fluorescence emission spectra of a dilute solution $(5.0 \mathrm{mg} / \mathrm{mL})$ of the control polymer with the addition of $30 \mathrm{mM} \mathrm{BHT}$ inhibitor upon ultrasonication for different times with excitation wavelength of $370 \mathrm{~nm}$.

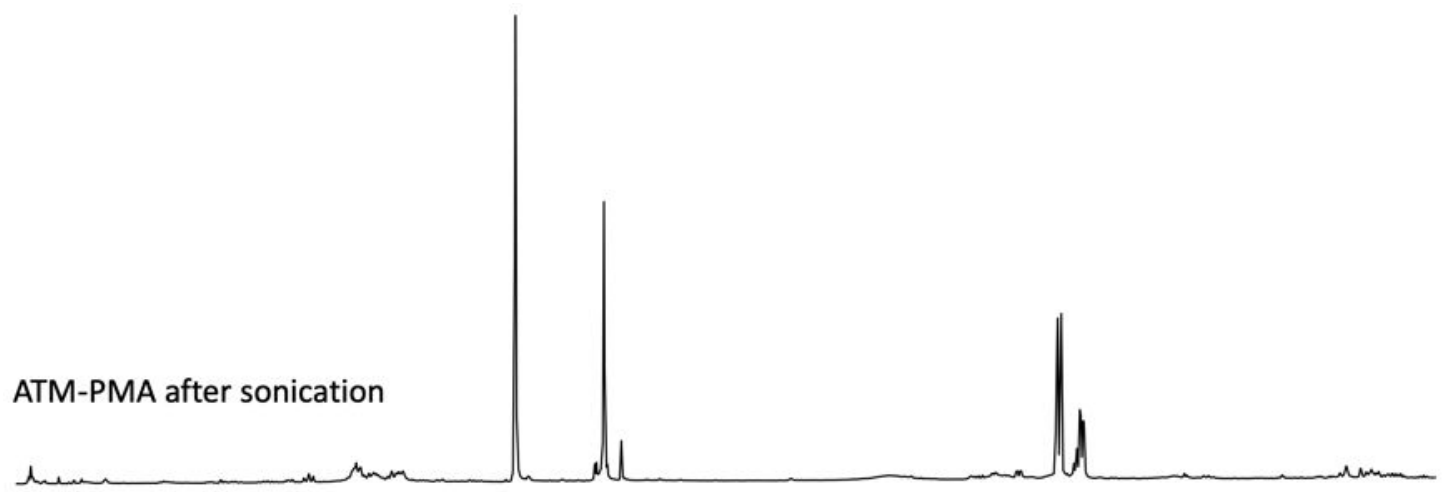

reference polymer when

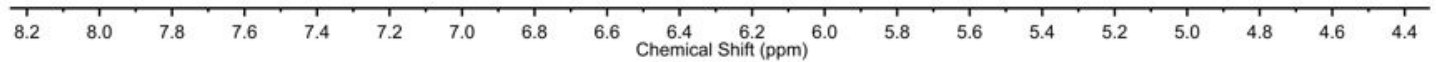

Figure S6. Comparison of ${ }^{1} \mathrm{H}-\mathrm{NMR}$ spectra of ATM-PMA after ultrasonication for $180 \mathrm{~min}$ and the reference polymer in DMSO-d6. 


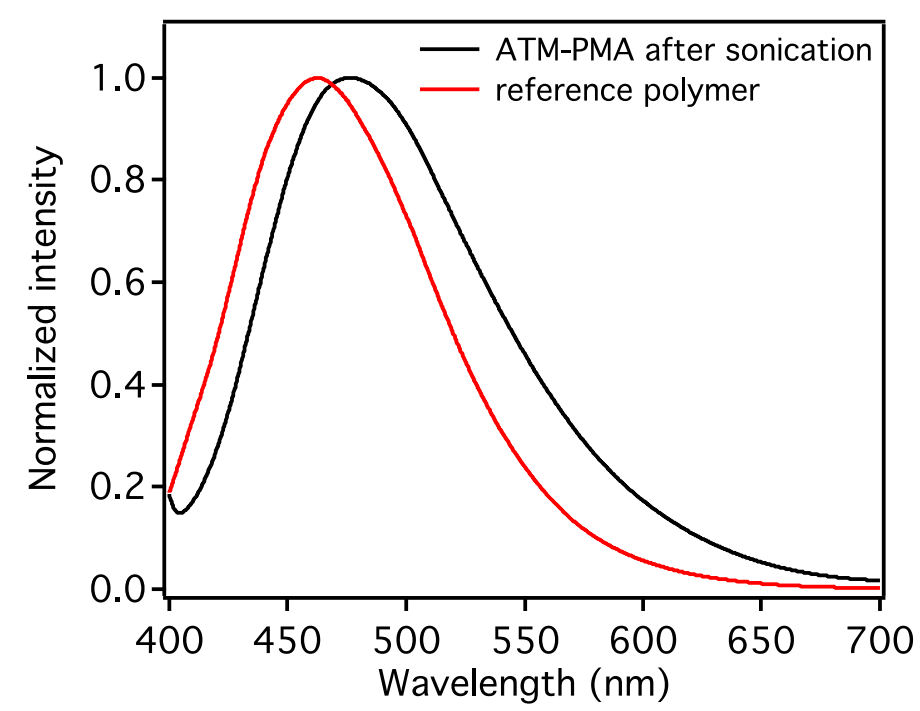

Figure S7. Normalized fluorescence emission spectra of ATM-PMA after ultrasonication for $180 \mathrm{~min}$ and the reference polymer. Fluorescence was measured at polymer concentration of $5.0 \mathrm{mg} / \mathrm{mL}$ in THF with excitation wavelength of $370 \mathrm{~nm}$.

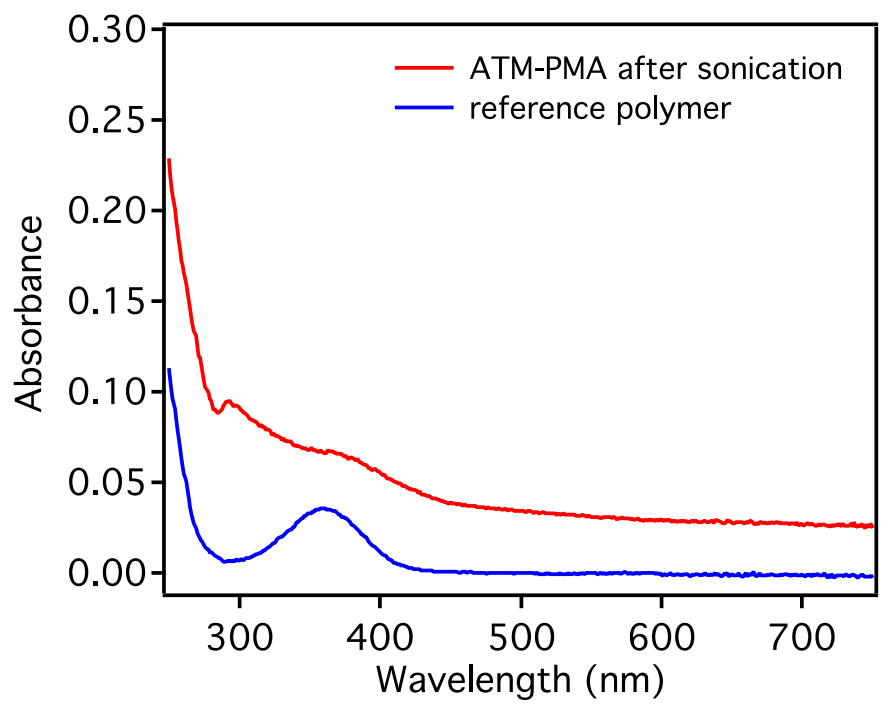

Figure S8. UV-vis spectra of ATM-PMA after ultrasonication for $180 \mathrm{~min}$ and the reference polymer. Absorbance was measured at polymer concentration of $5.0 \mathrm{mg} / \mathrm{mL}$ in THF. 


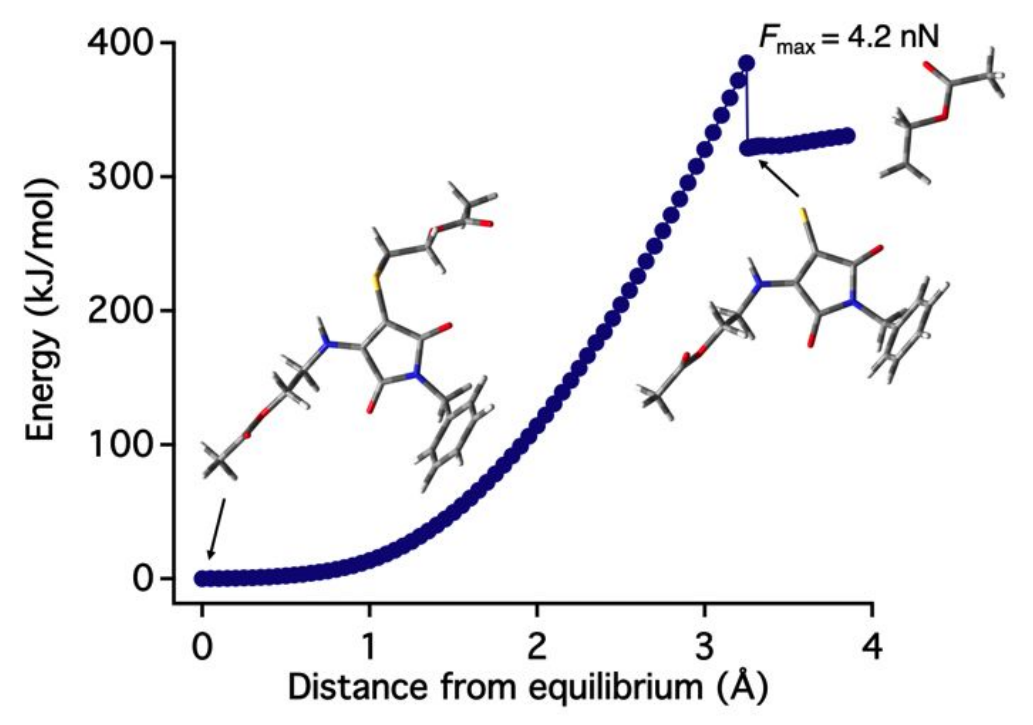

Figure S9. DFT calculations of mechanical elongation of a truncated ATM with terminal acetyl groups using the constrained geometries simulate external force (CoGEF) method at the B3LYP/6-31G* level of theory. Starting from the equilibrium geometry of the unconstrained molecule, the distance between the methyl carbon atoms of the truncated structure was artificially constrained and increased in increments of $0.05 \AA$, and the energy was minimized at each interval. The maximum force at rupture $\left(F_{\max }\right)$ is estimated to be $4.2 \mathrm{nN}$ with a calculated energy barrier of $385 \mathrm{~kJ} / \mathrm{mol}^{2}$

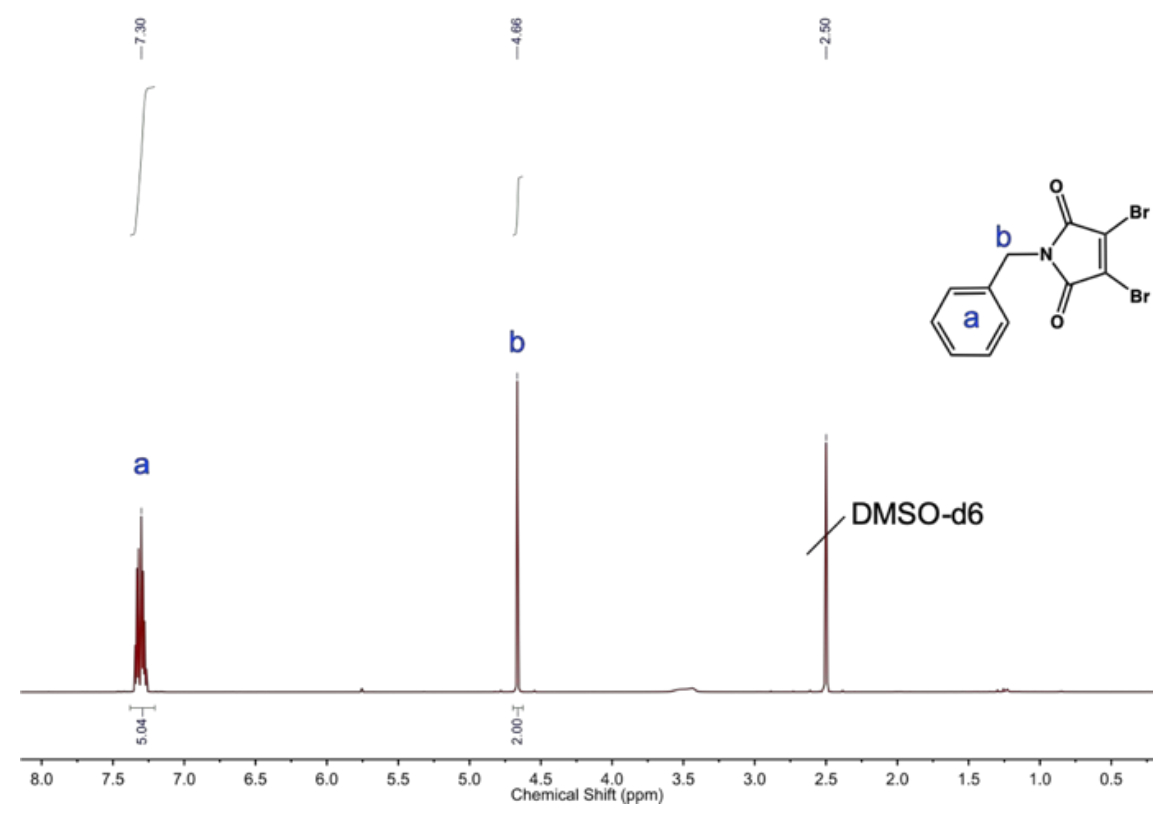

Figure S10. ${ }^{1} \mathrm{H}-\mathrm{NMR}$ spectrum of Compound 2 in DMSO-d6. 


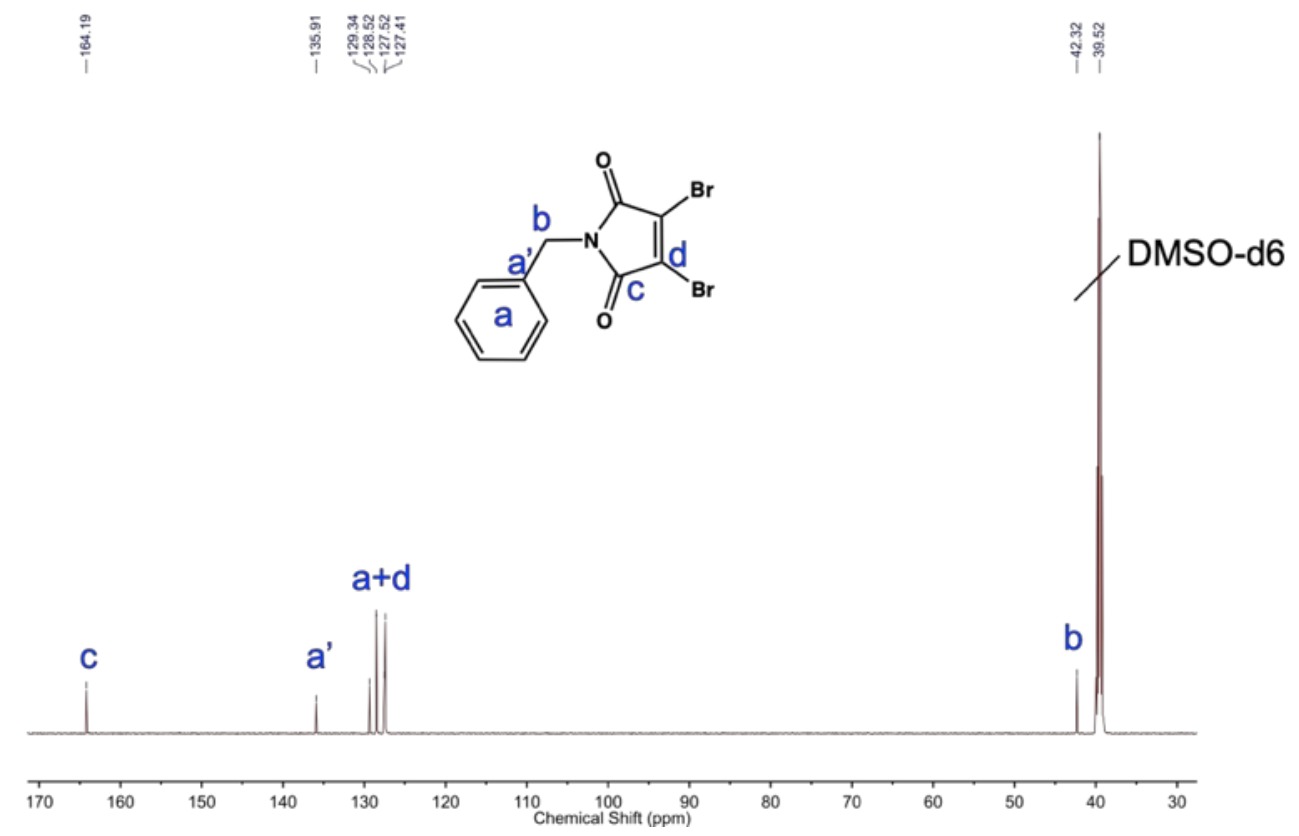

Figure S11. ${ }^{13}$ C-NMR spectrum of Compound 2 in DMSO-d6.

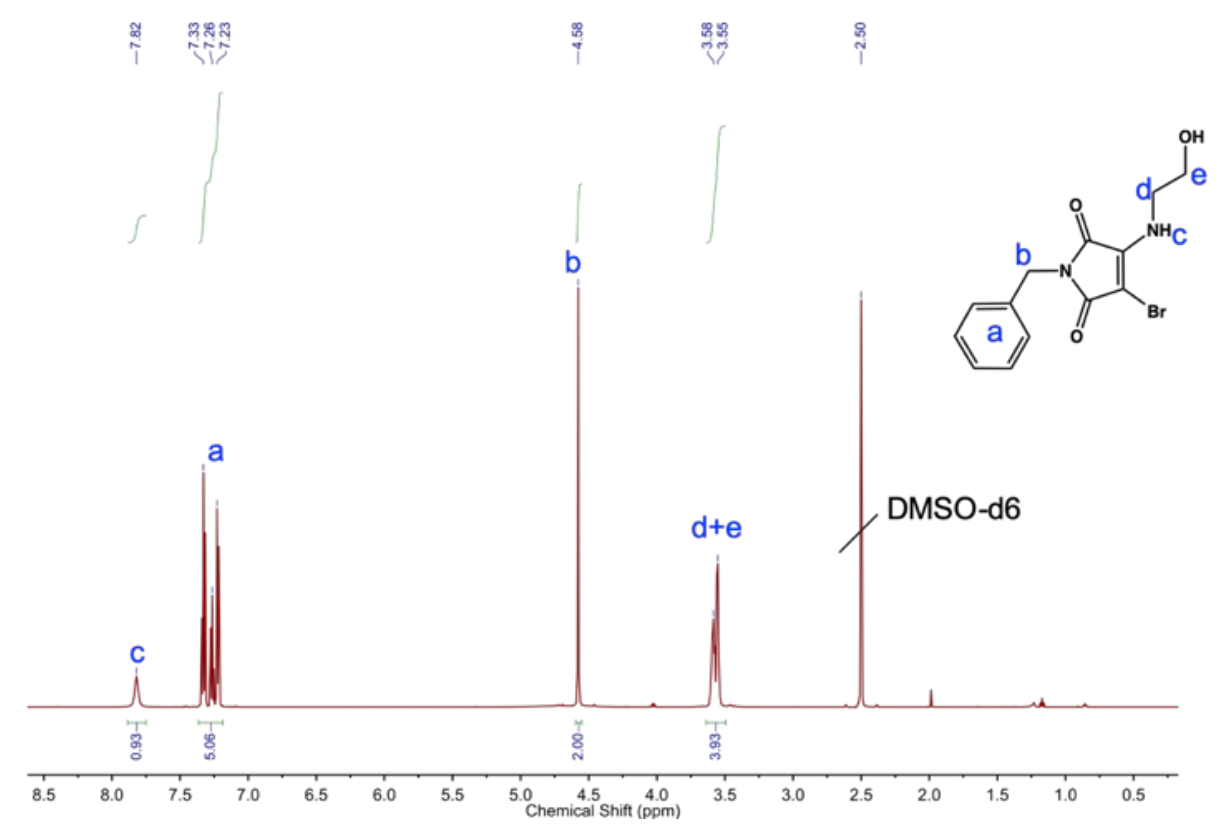

Figure S12. ${ }^{1} \mathrm{H}-\mathrm{NMR}$ spectrum of Compound 3 in DMSO-d6. 


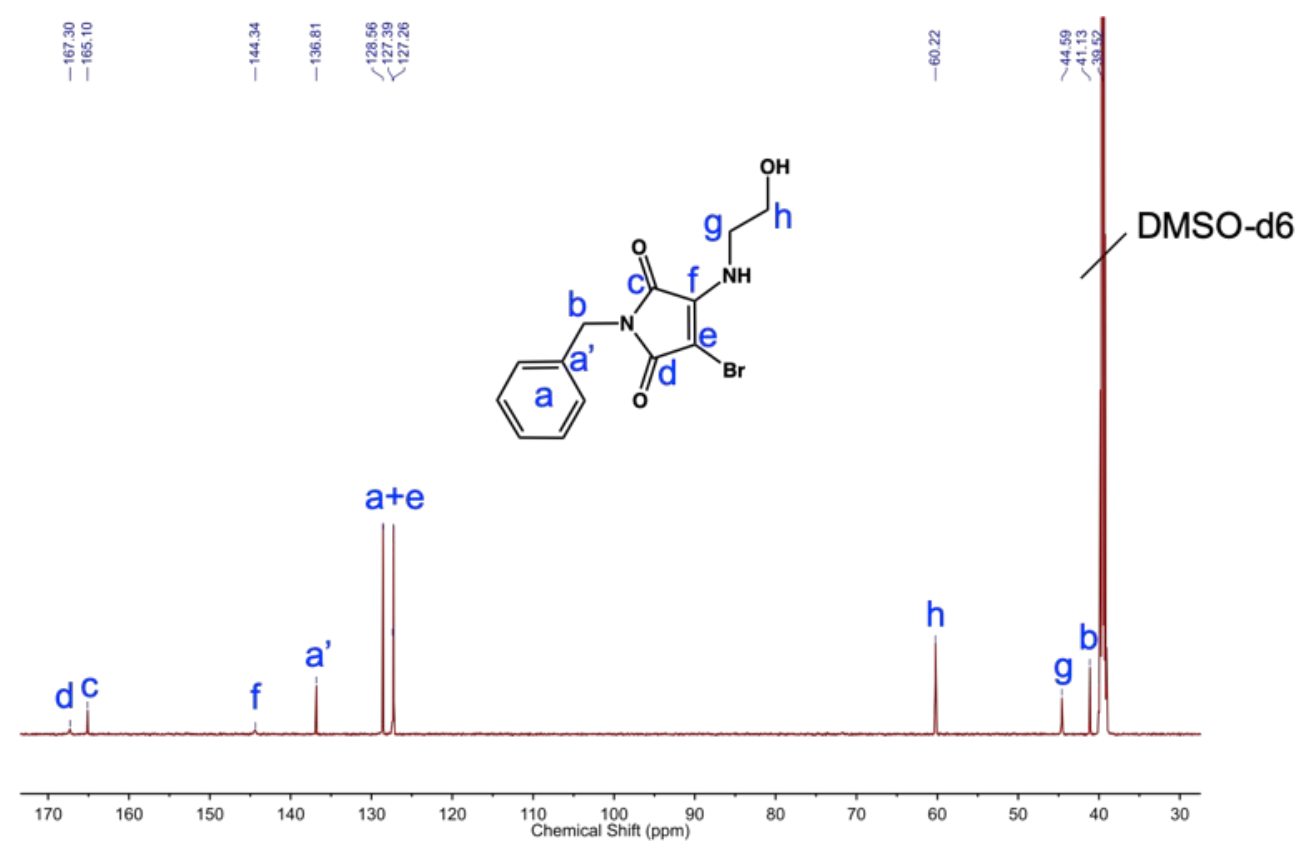

Figure S13. ${ }^{13} \mathrm{C}-\mathrm{NMR}$ spectrum of Compound 3 in DMSO-d6.

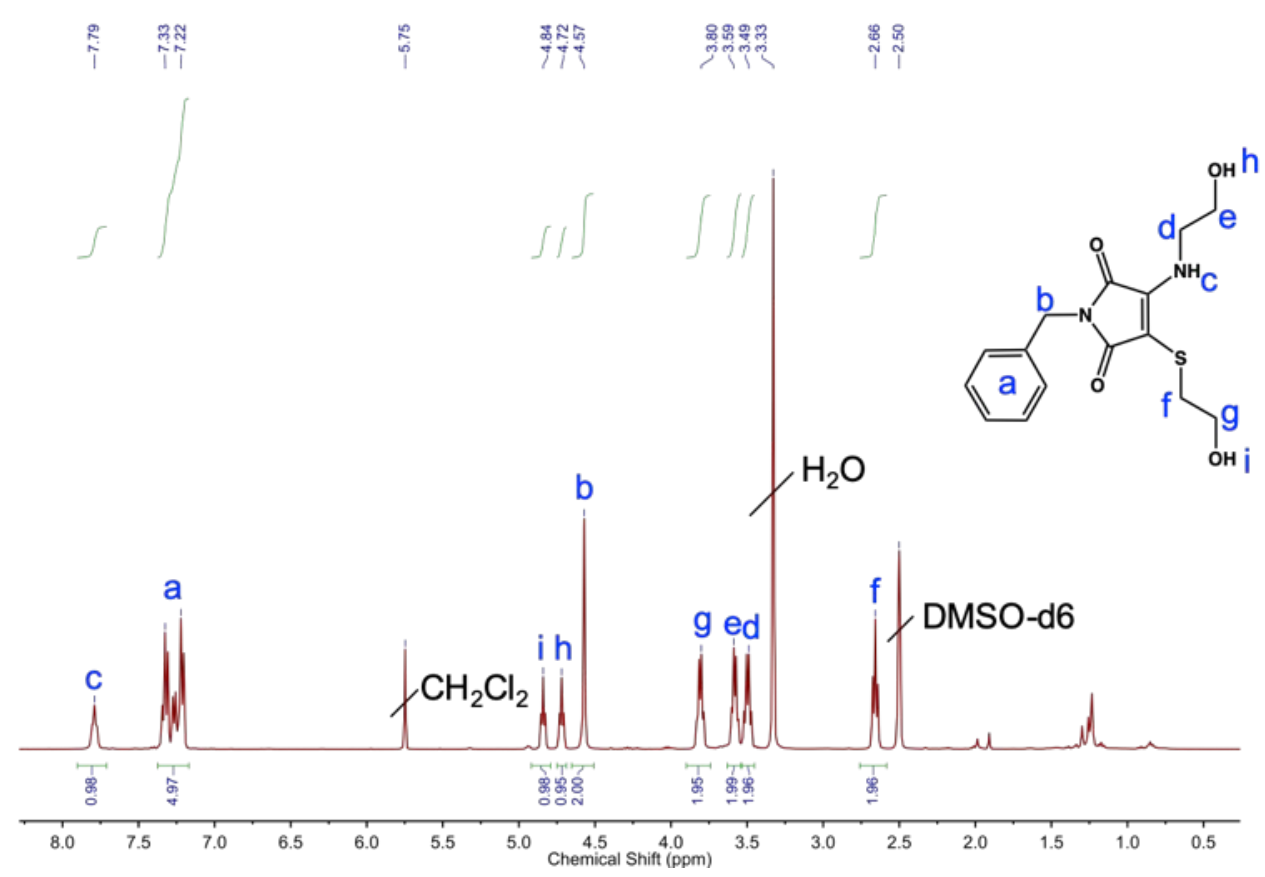

Figure S14. ${ }^{1} \mathrm{H}-\mathrm{NMR}$ spectrum of Compound 4 in DMSO-d6. 


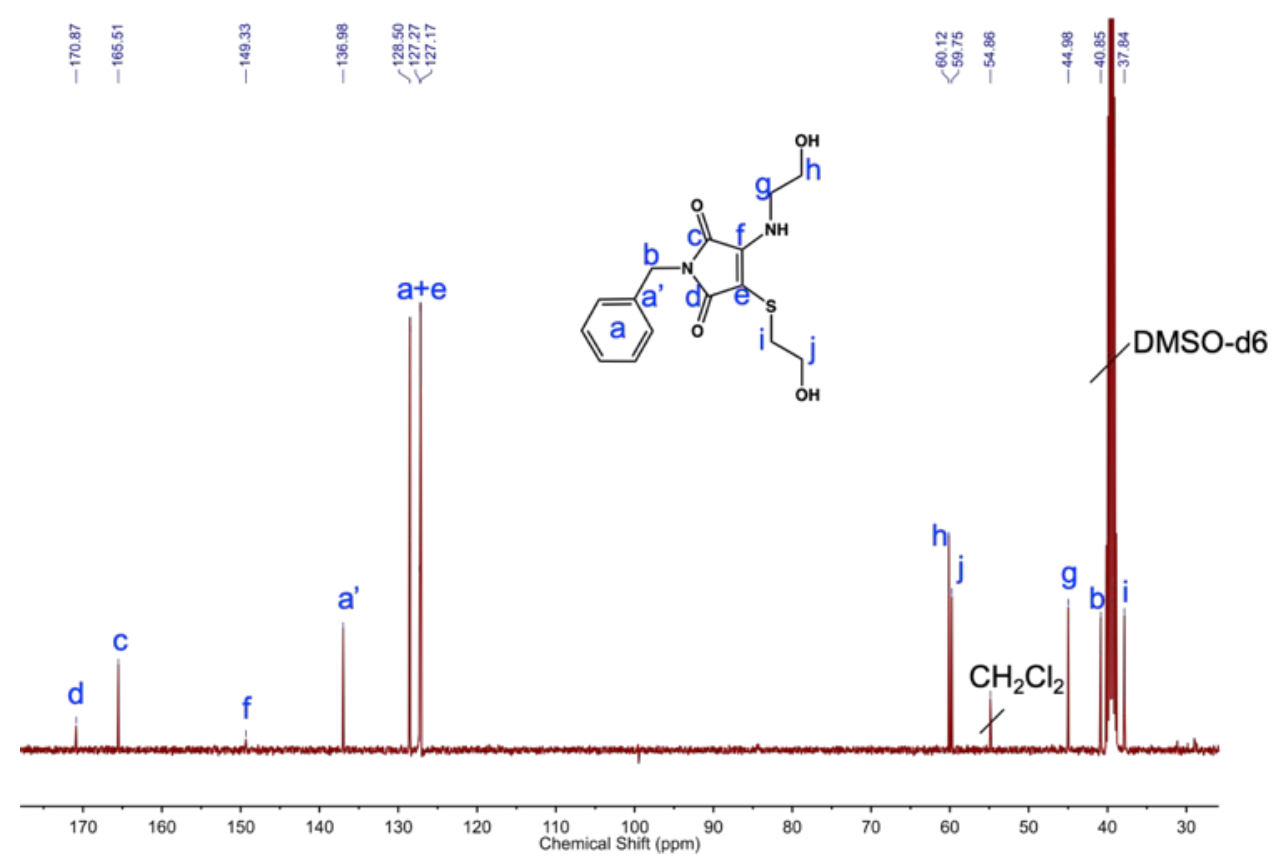

Figure S15. ${ }^{13} \mathrm{C}-\mathrm{NMR}$ spectrum of Compound 4 in DMSO-d6.

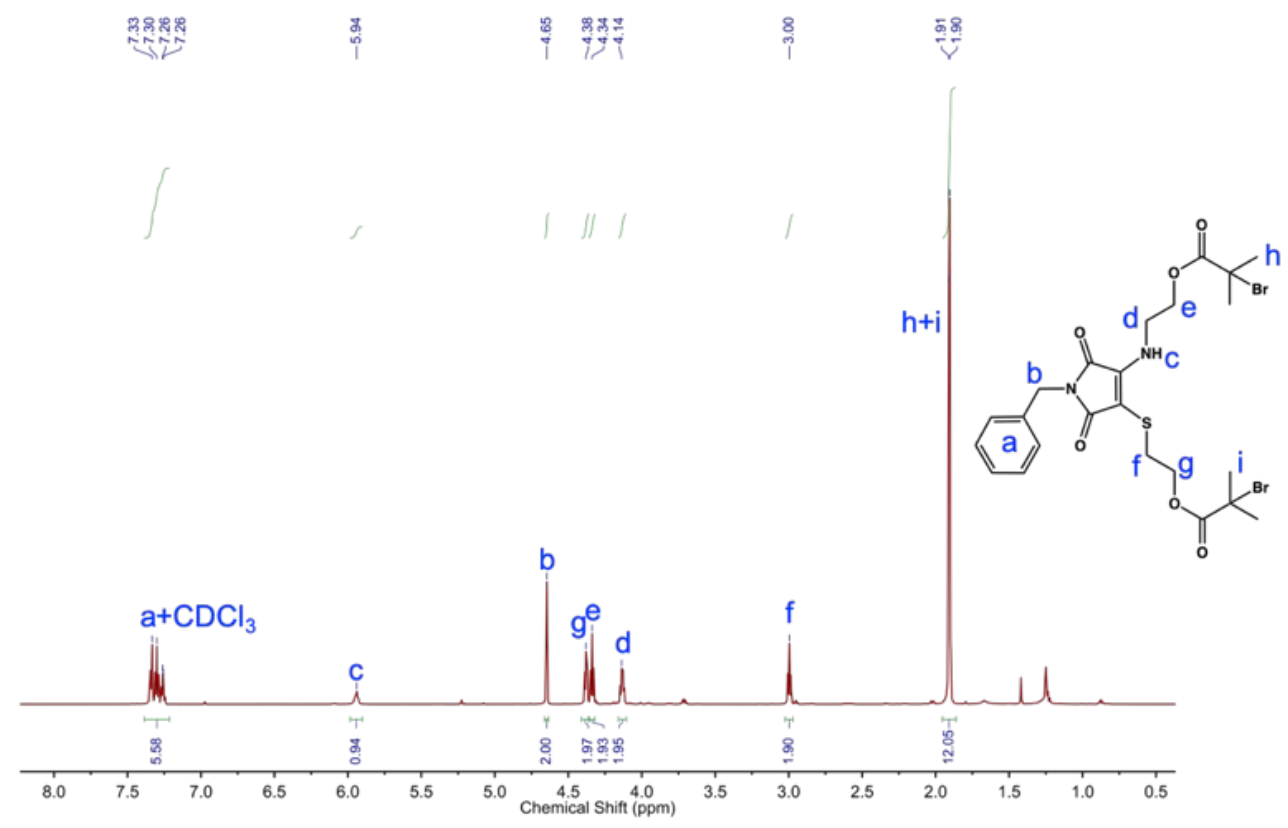

Figure S16. ${ }^{1} \mathrm{H}-\mathrm{NMR}$ spectrum of Compound 5 in $\mathrm{CDCl}_{3}$. 


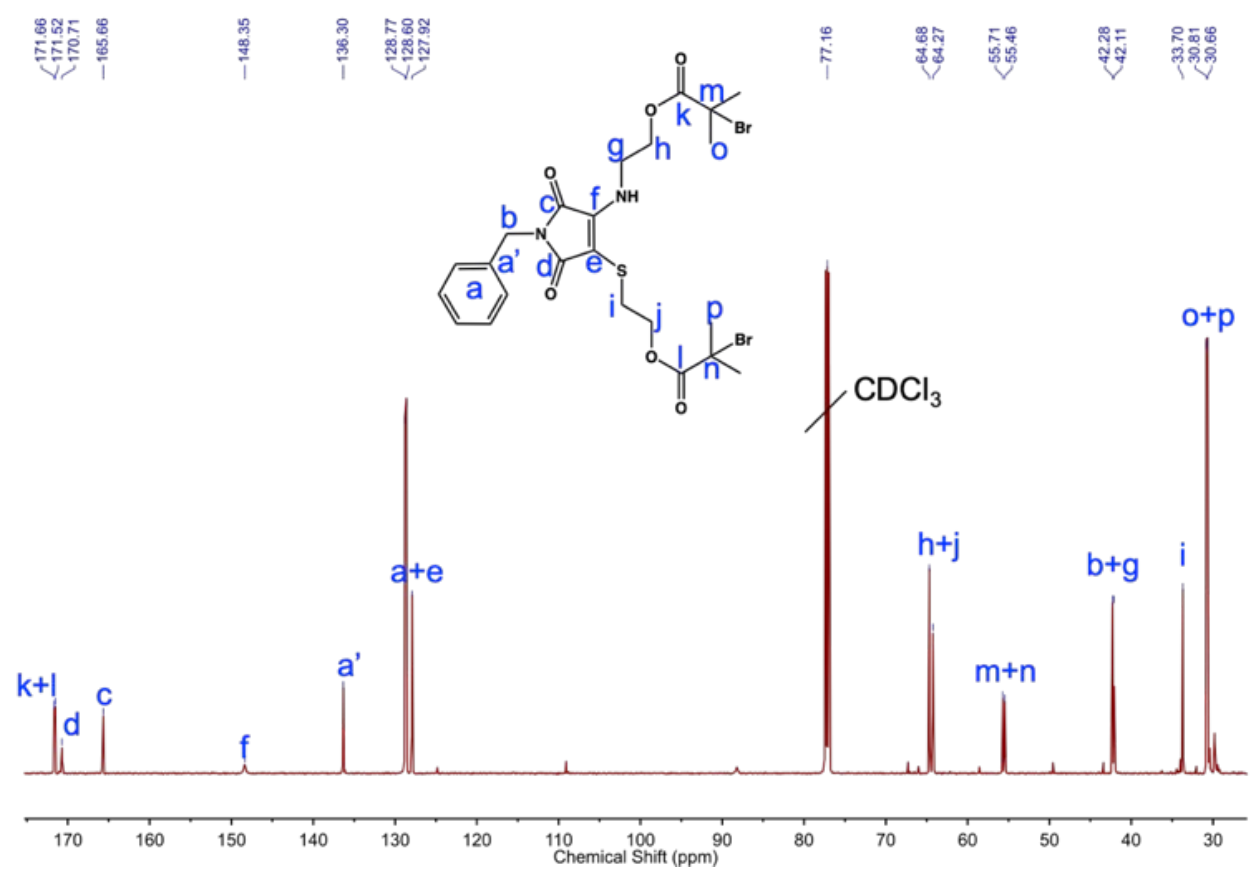

Figure S17. ${ }^{13} \mathrm{C}-\mathrm{NMR}$ spectrum of Compound 5 in $\mathrm{CDCl}_{3}$.

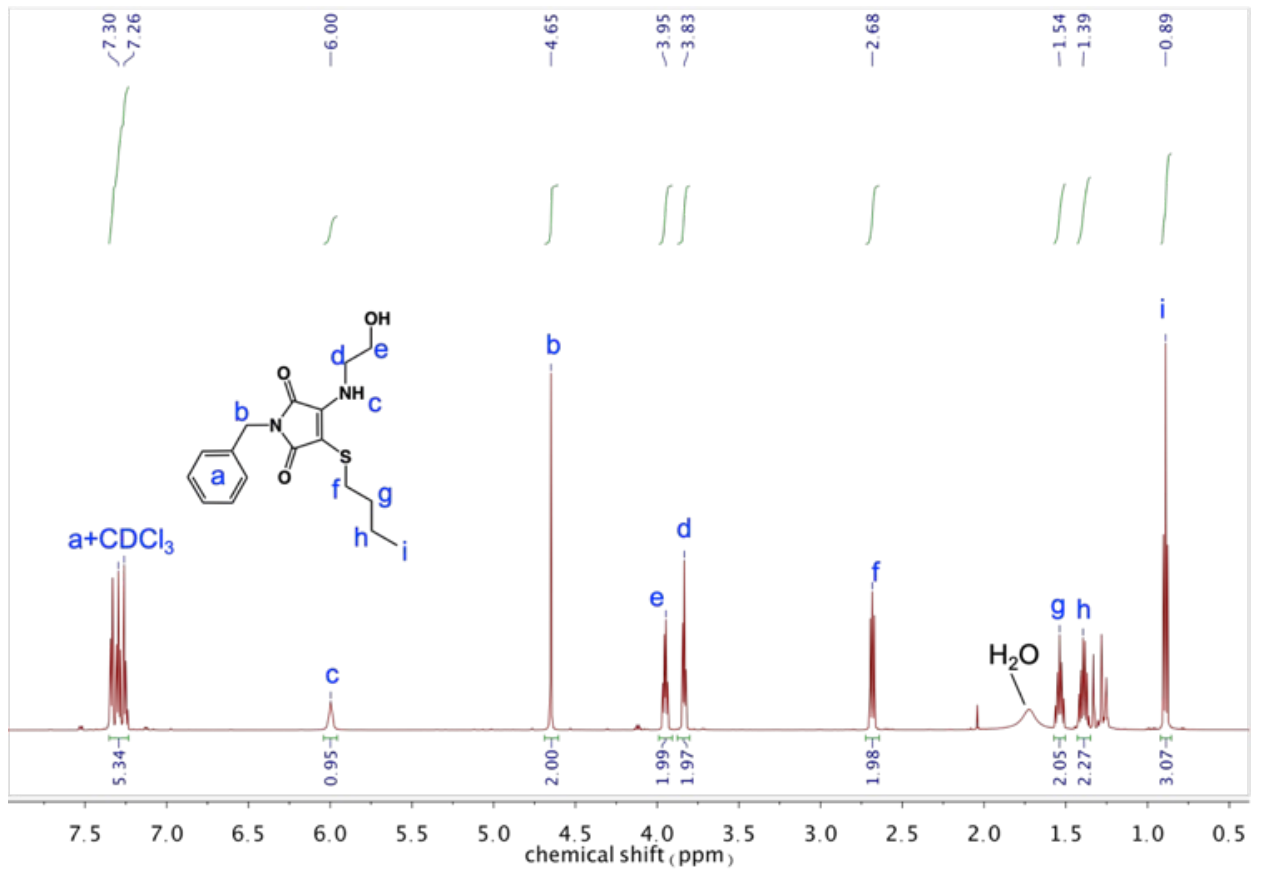

Figure S18. ${ }^{1} \mathrm{H}-\mathrm{NMR}$ spectrum of Compound 6 in $\mathrm{CDCl}_{3}$. 


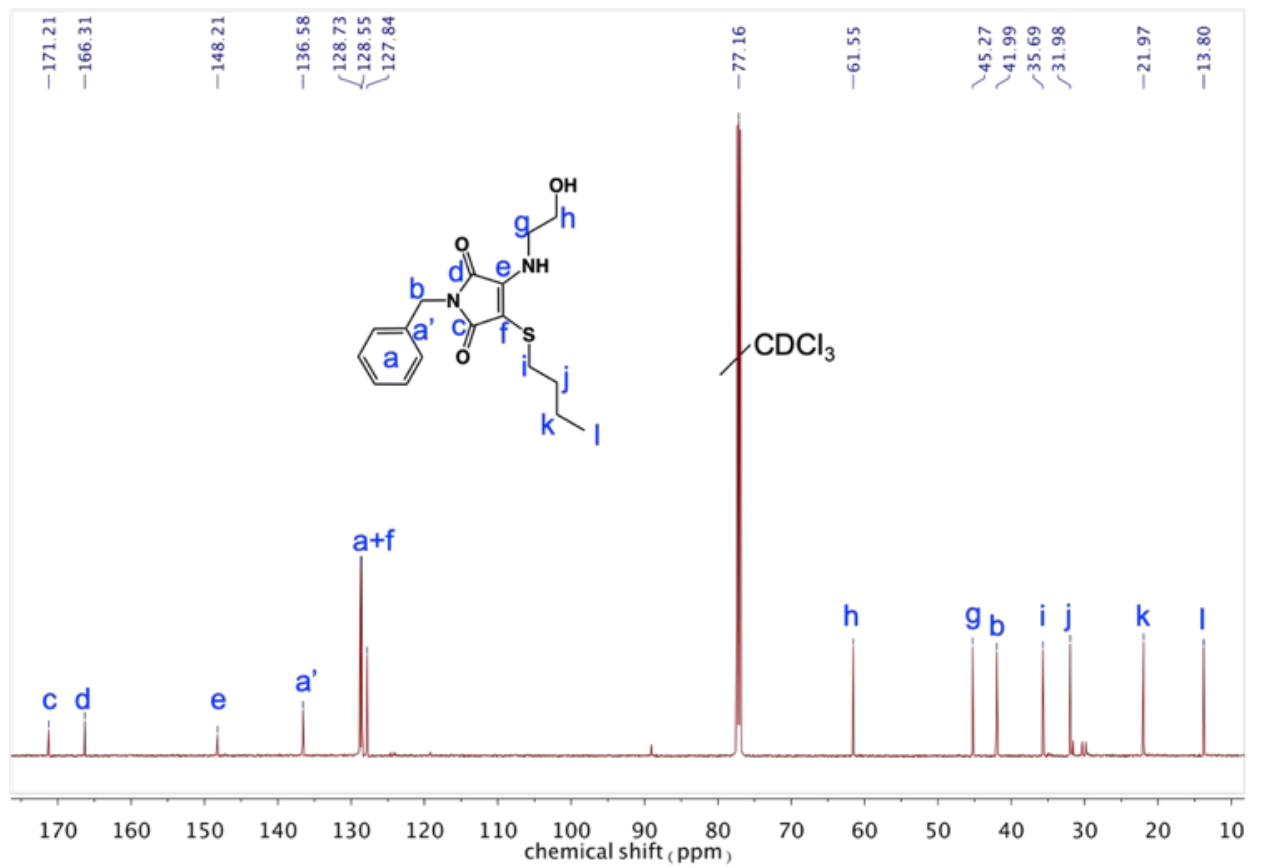

Figure S19. ${ }^{13} \mathrm{C}$-NMR spectrum of Compound 6 in $\mathrm{CDCl}_{3}$.

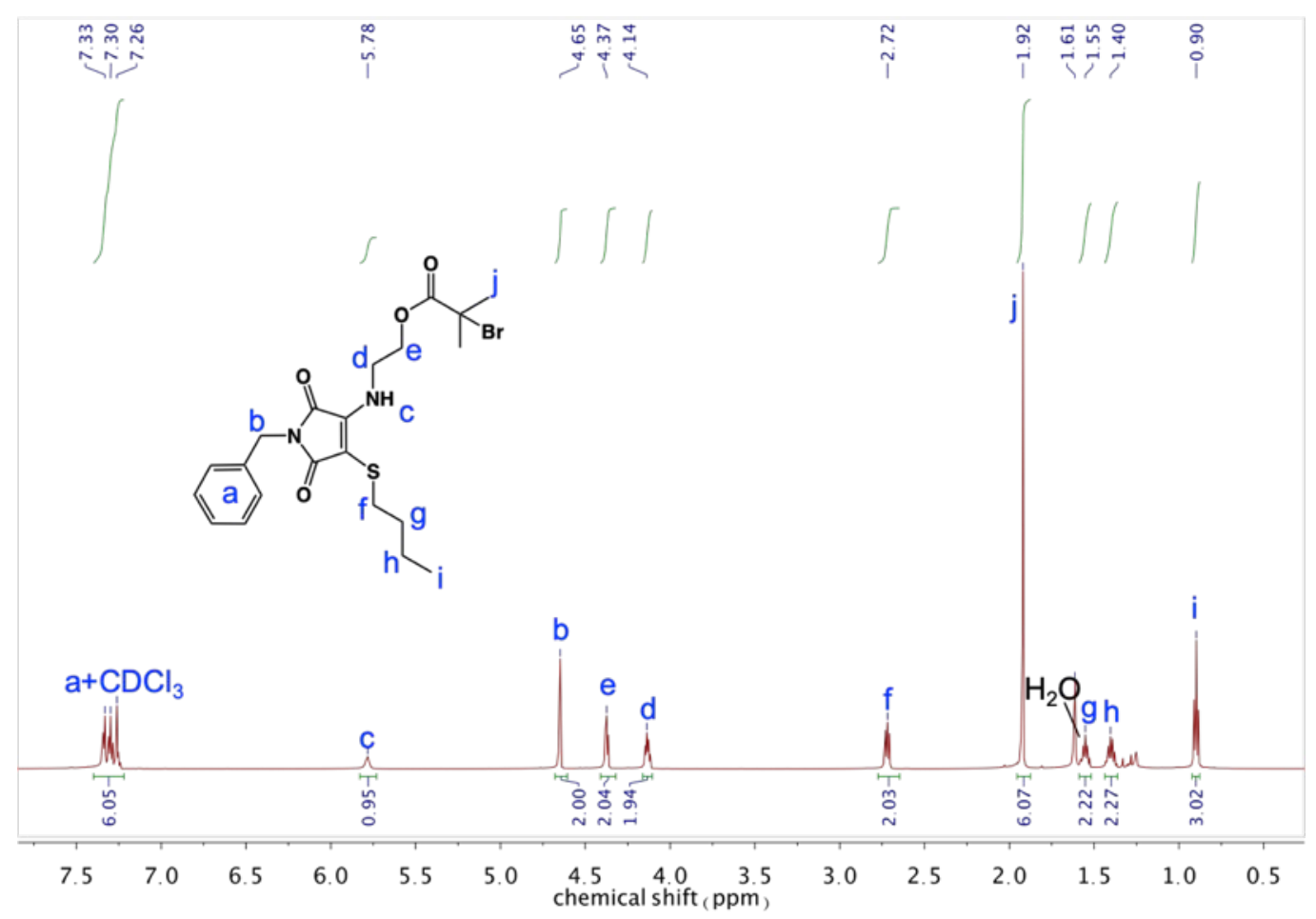

Figure S20. ${ }^{1} \mathrm{H}-\mathrm{NMR}$ spectrum of Compound 7 in $\mathrm{CDCl}_{3}$. 


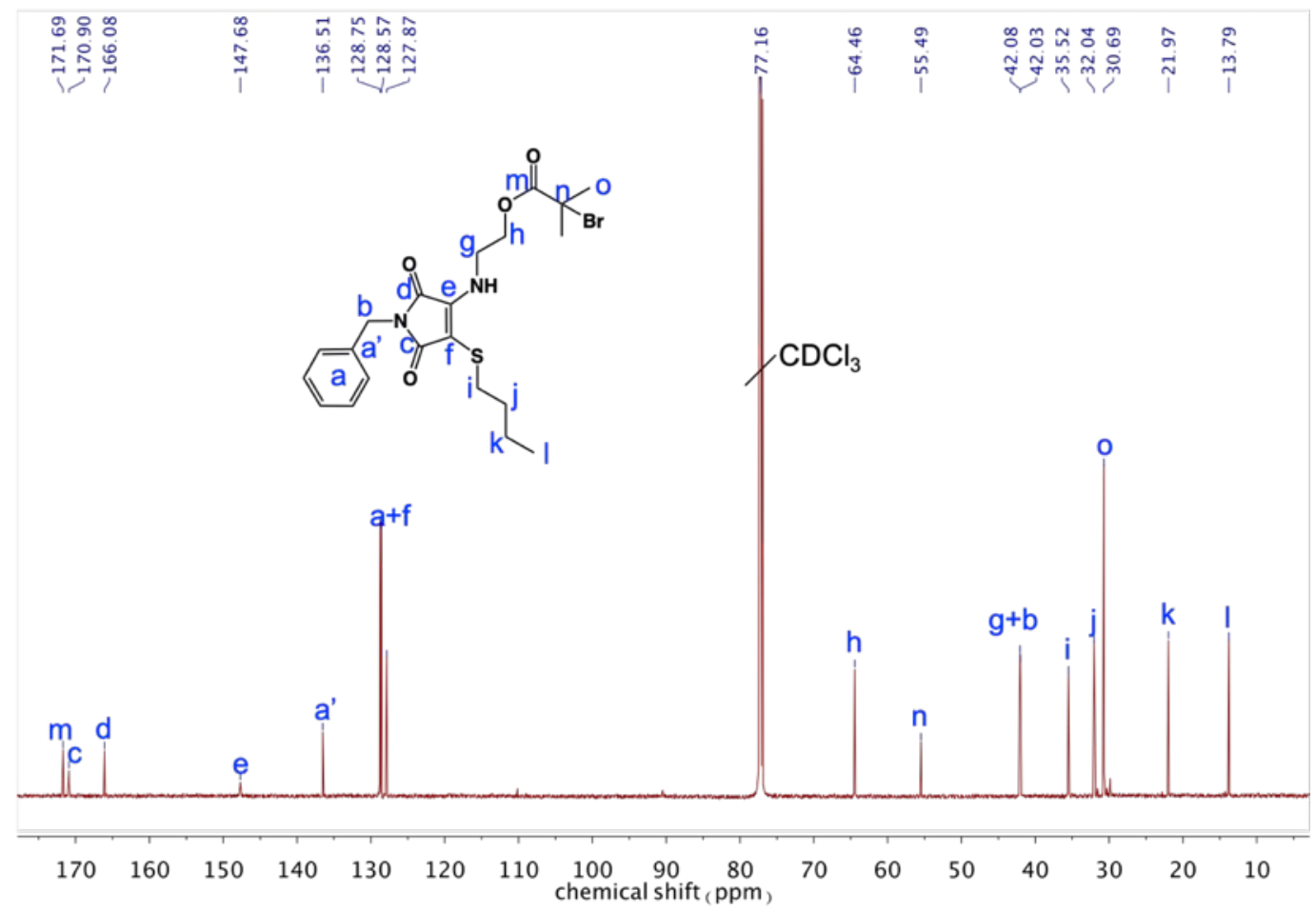

Figure S21. ${ }^{13} \mathrm{C}$-NMR spectrum of Compound 7 in $\mathrm{CDCl}_{3}$.

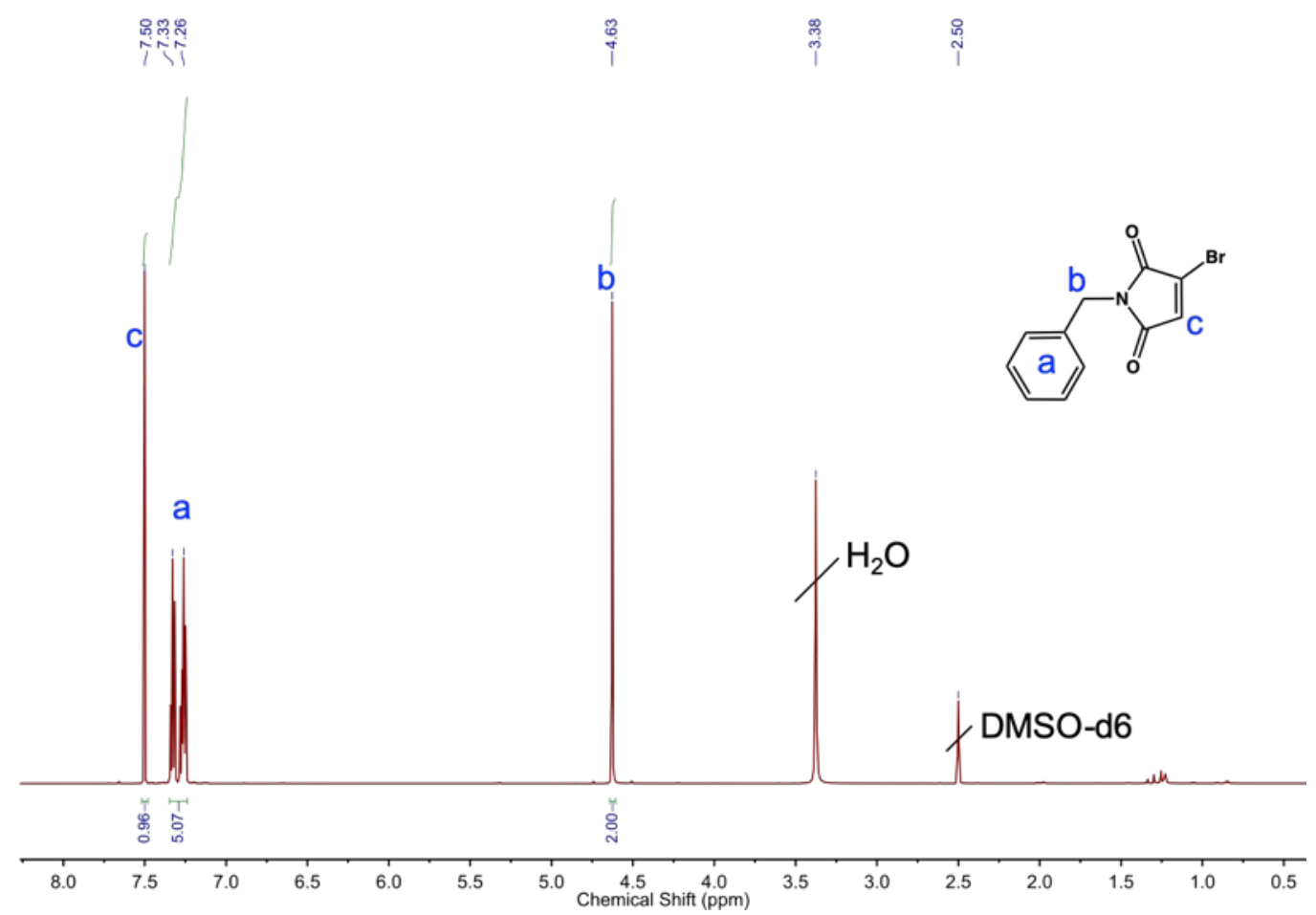

Figure S22. ${ }^{1} \mathrm{H}-\mathrm{NMR}$ spectrum of Compound 8 in DMSO-d6. 


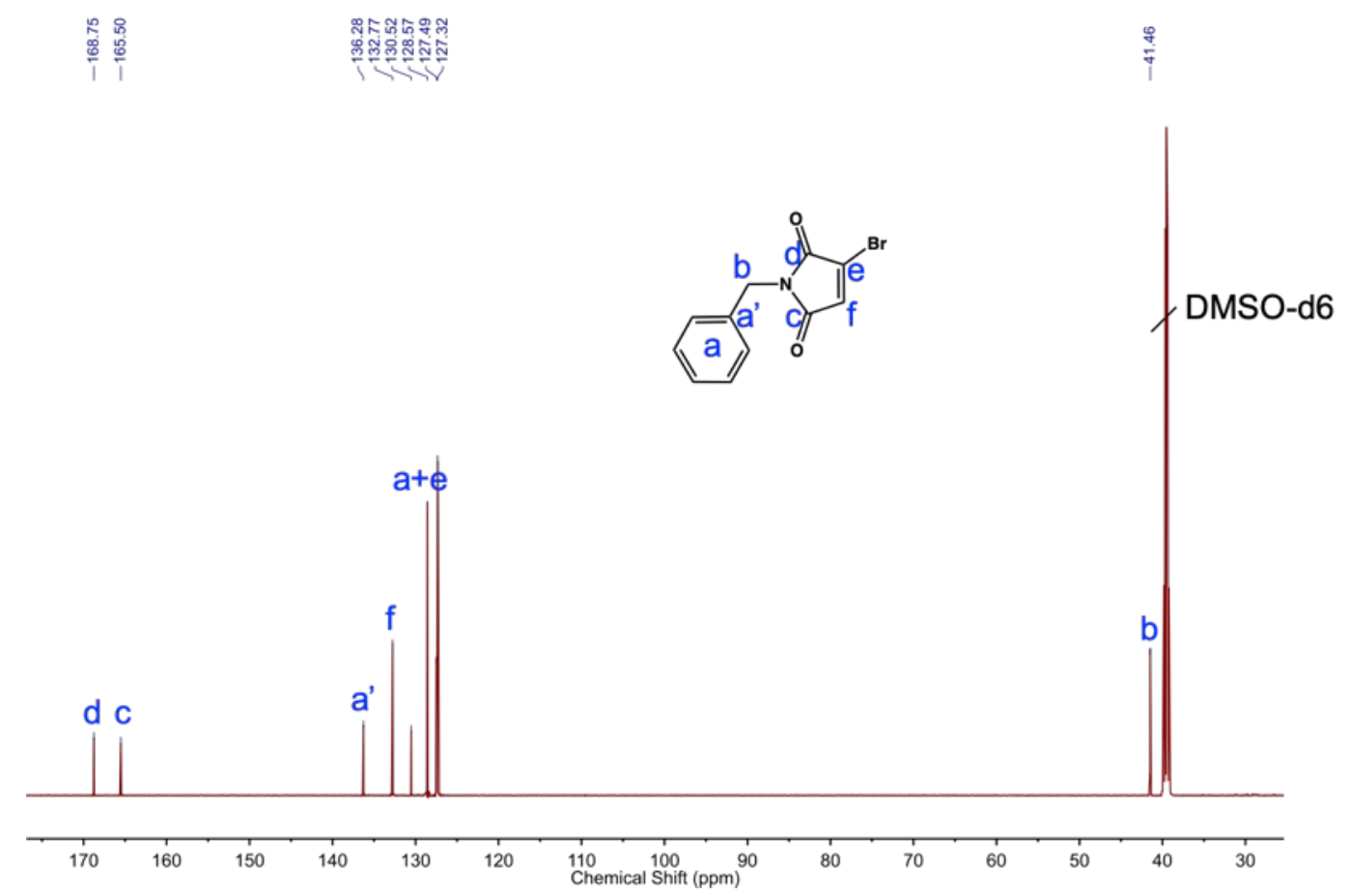

Figure S23. ${ }^{13} \mathrm{C}-\mathrm{NMR}$ spectrum of Compound $\mathbf{8}$ in DMSO-d6.

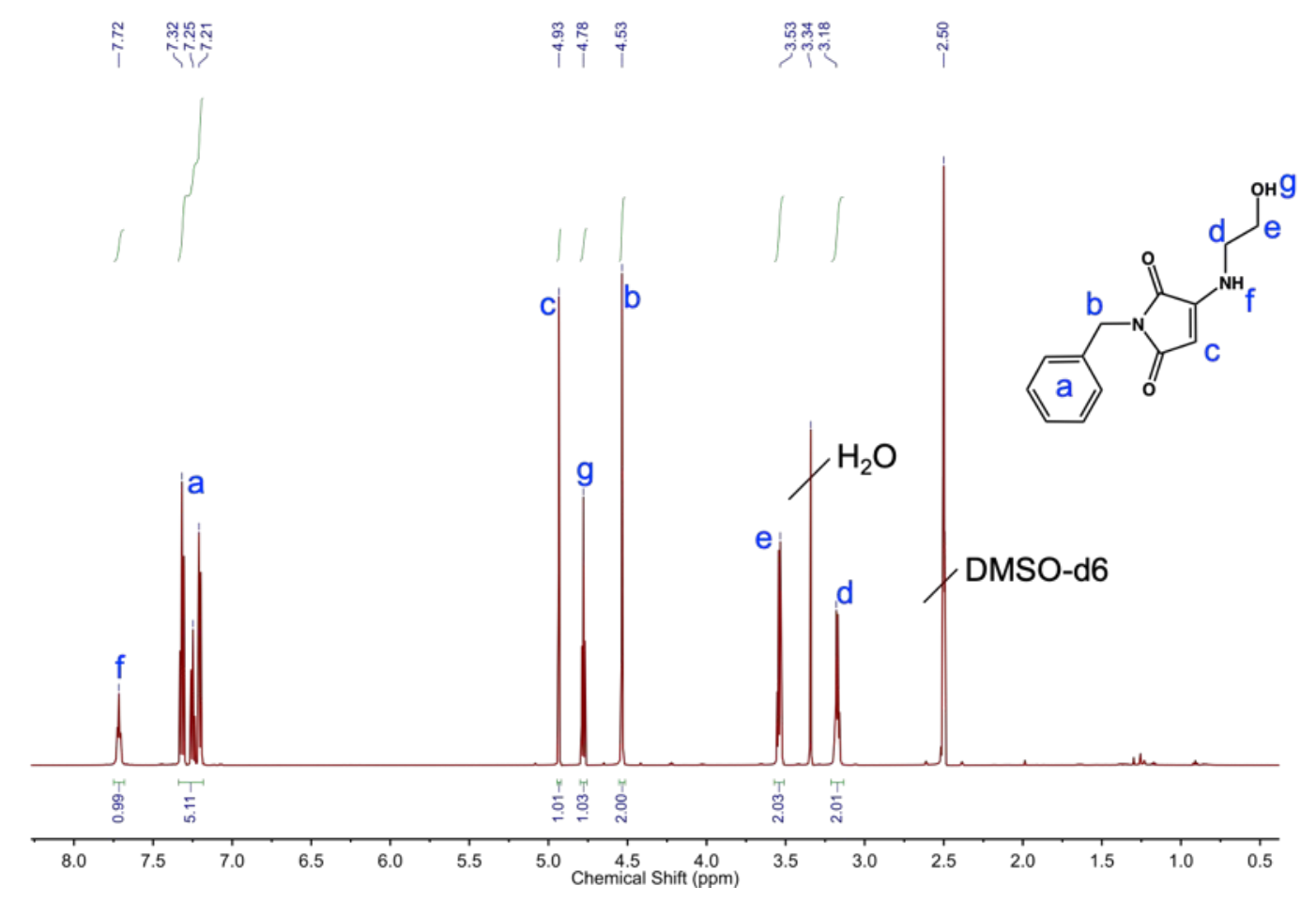

Figure S24. ${ }^{1} \mathrm{H}-\mathrm{NMR}$ spectrum of Compound 9 in DMSO-d6. 


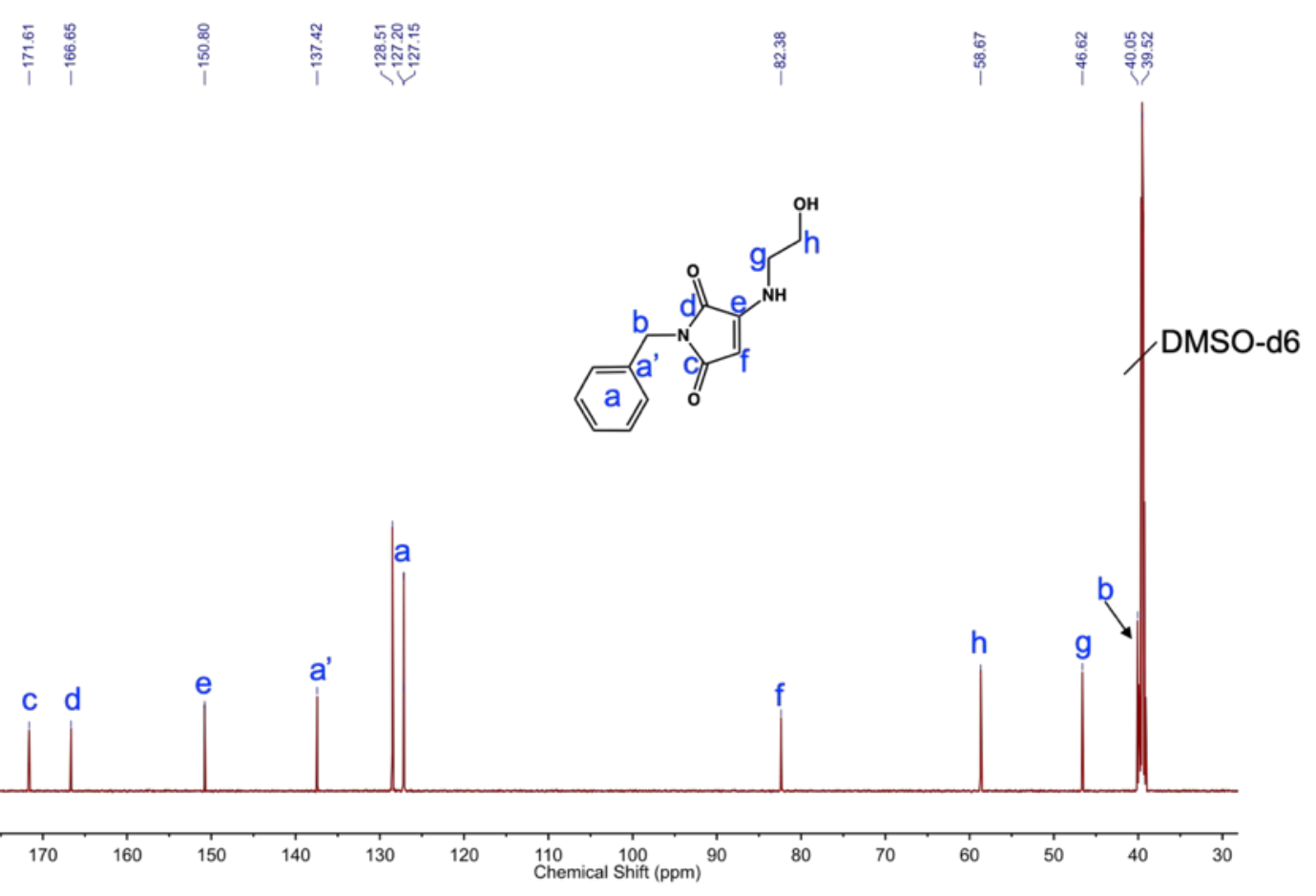

Figure S25. ${ }^{13} \mathrm{C}-\mathrm{NMR}$ spectrum of Compound 9 in DMSO-d6.

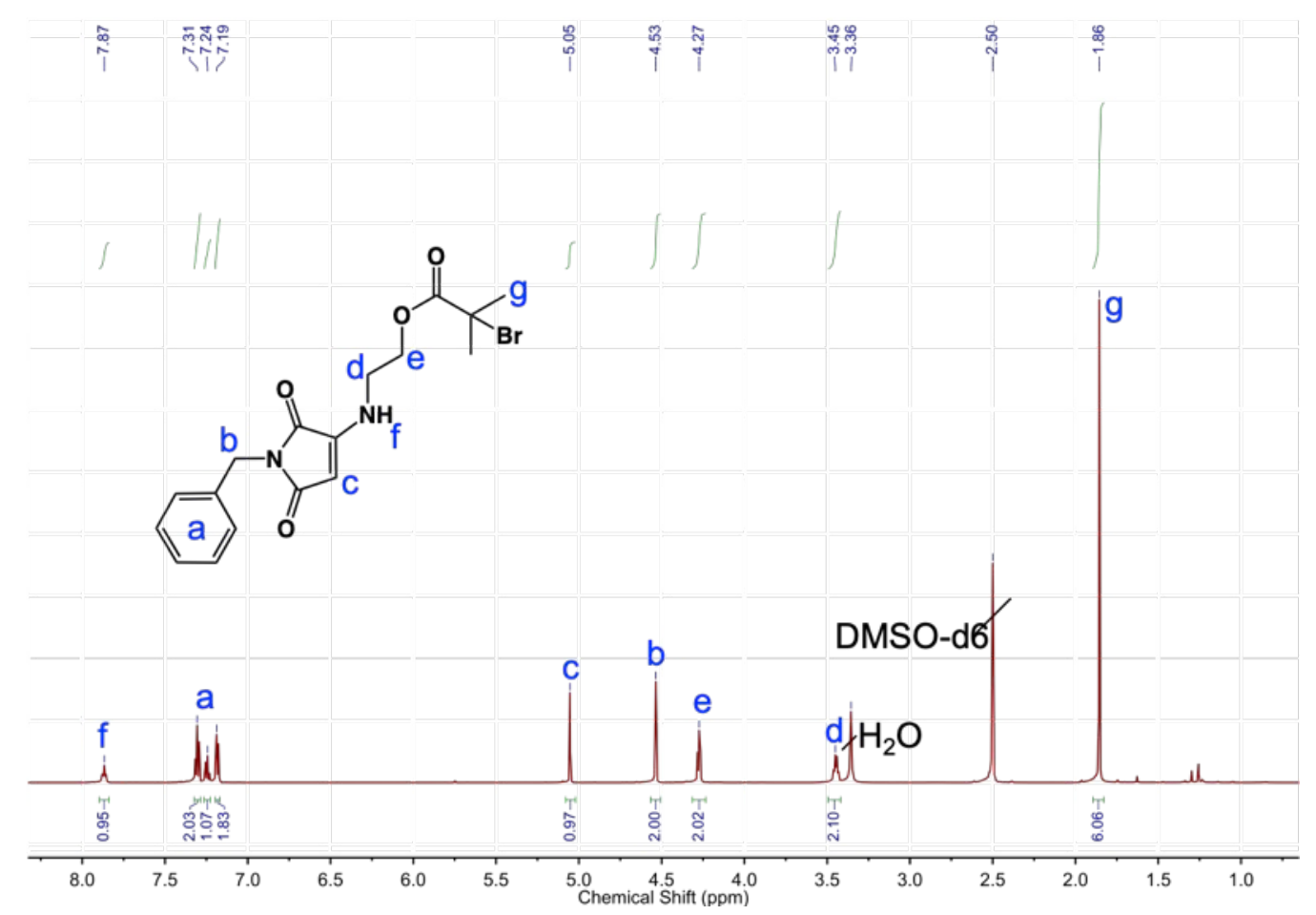

Figure S26. ${ }^{1} \mathrm{H}-\mathrm{NMR}$ spectrum of Compound 10 in DMSO-d6. 


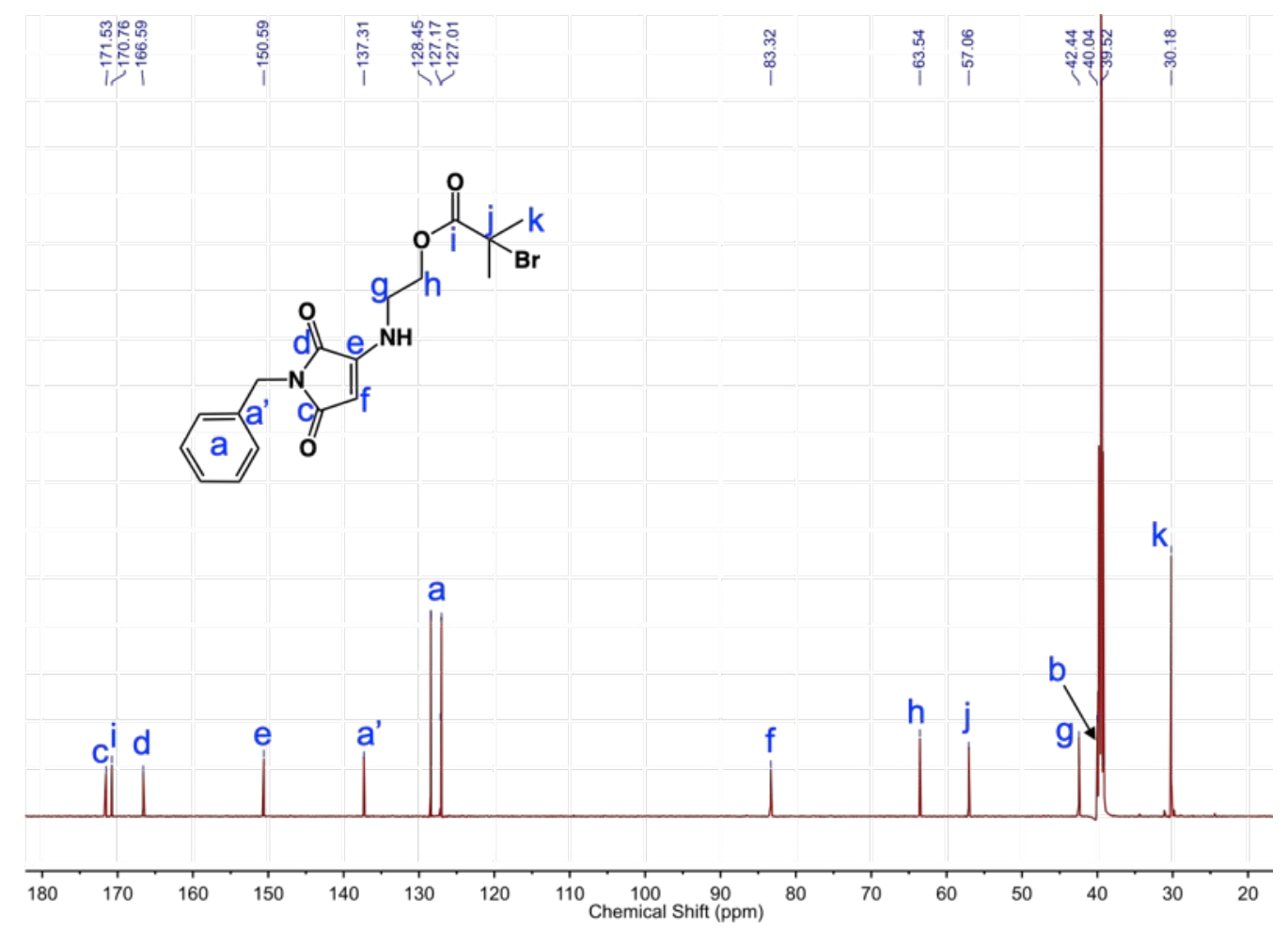

Figure S27. ${ }^{13} \mathrm{C}-\mathrm{NMR}$ spectrum of Compound 10 in DMSO-d6.

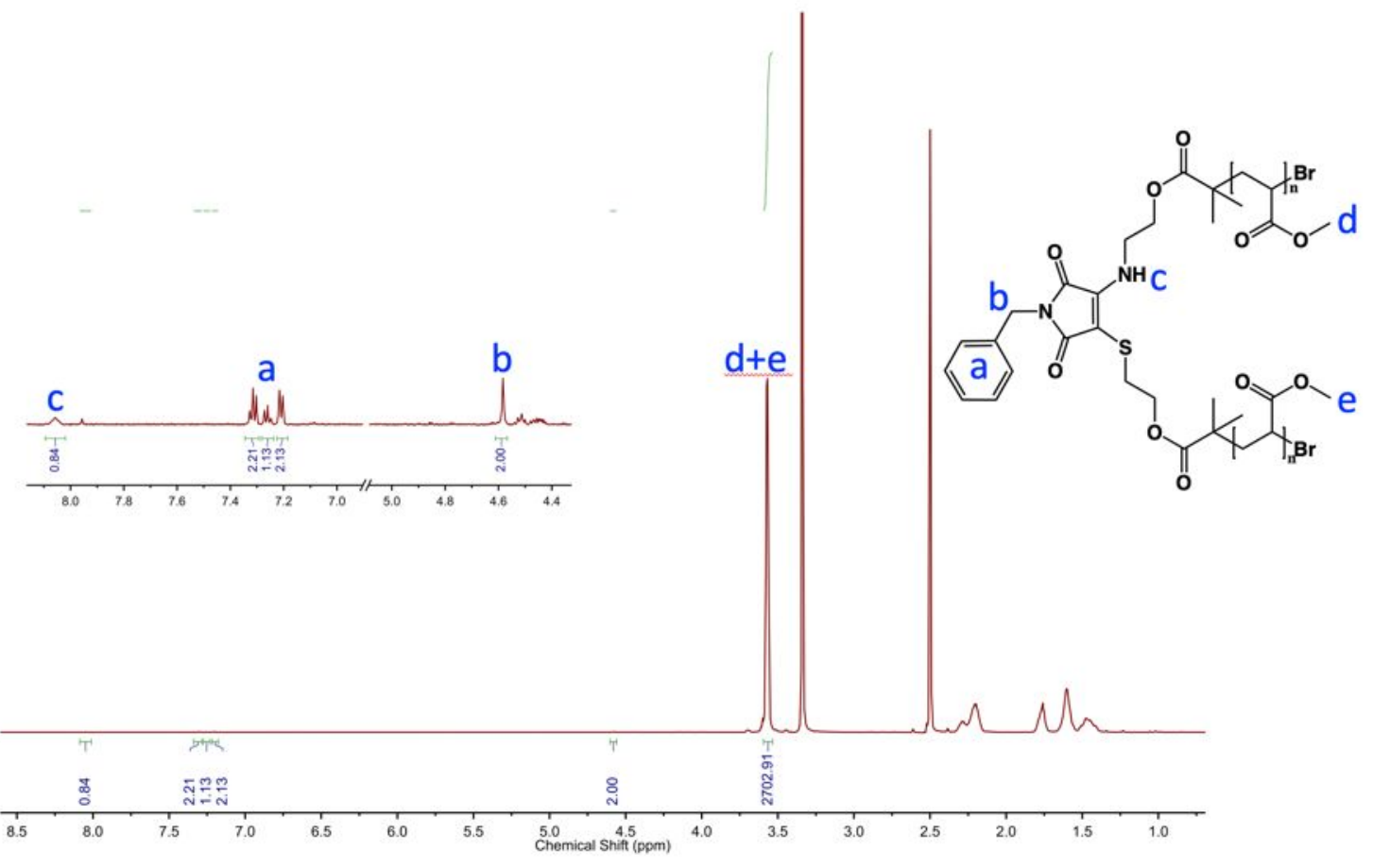

Figure S28. ${ }^{1} \mathrm{H}-\mathrm{NMR}$ spectrum of ATM-PMA in DMSO-d6. 


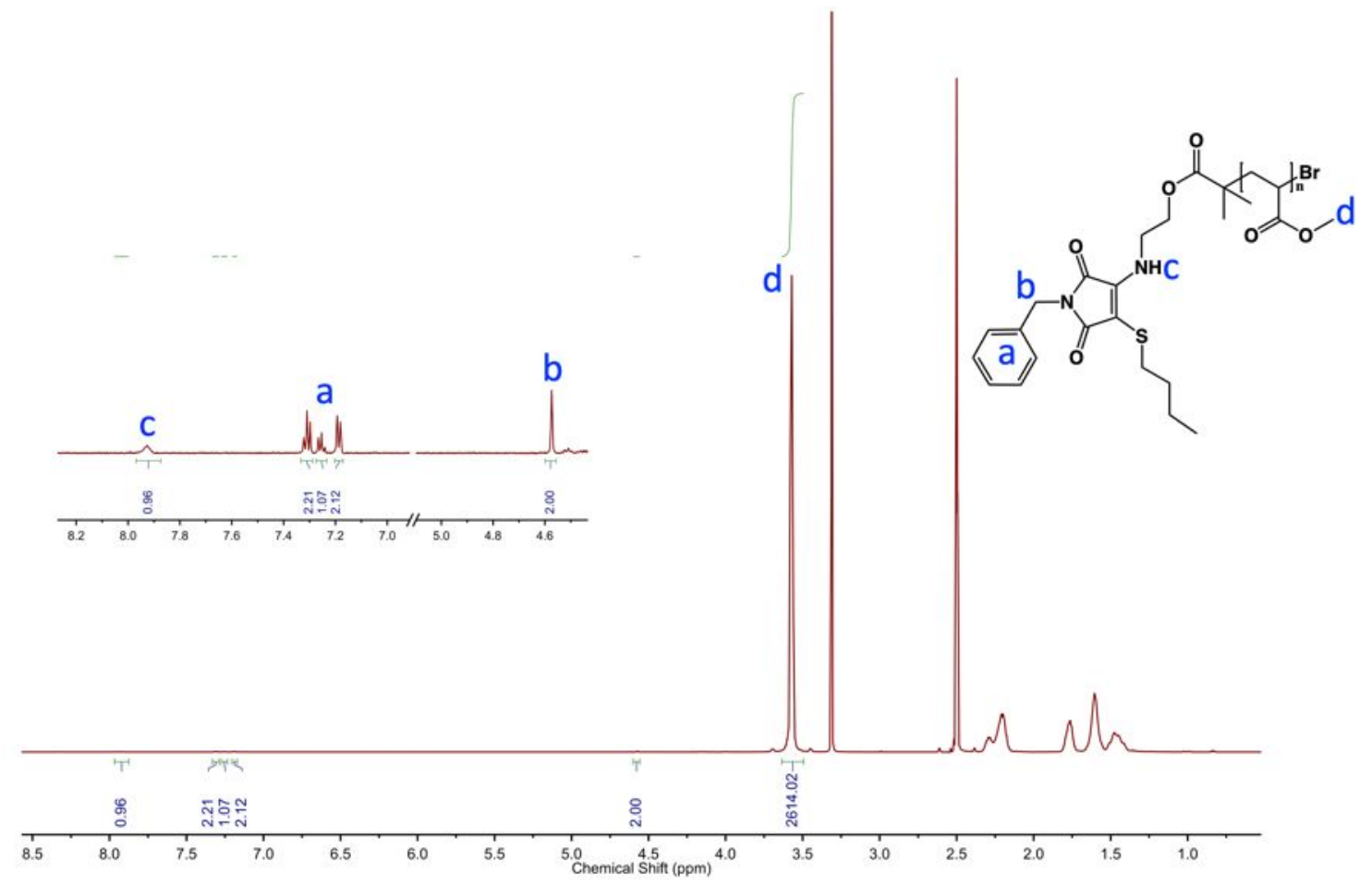

Figure S29. ${ }^{1} \mathrm{H}-\mathrm{NMR}$ spectrum of the control polymer in DMSO-d6.

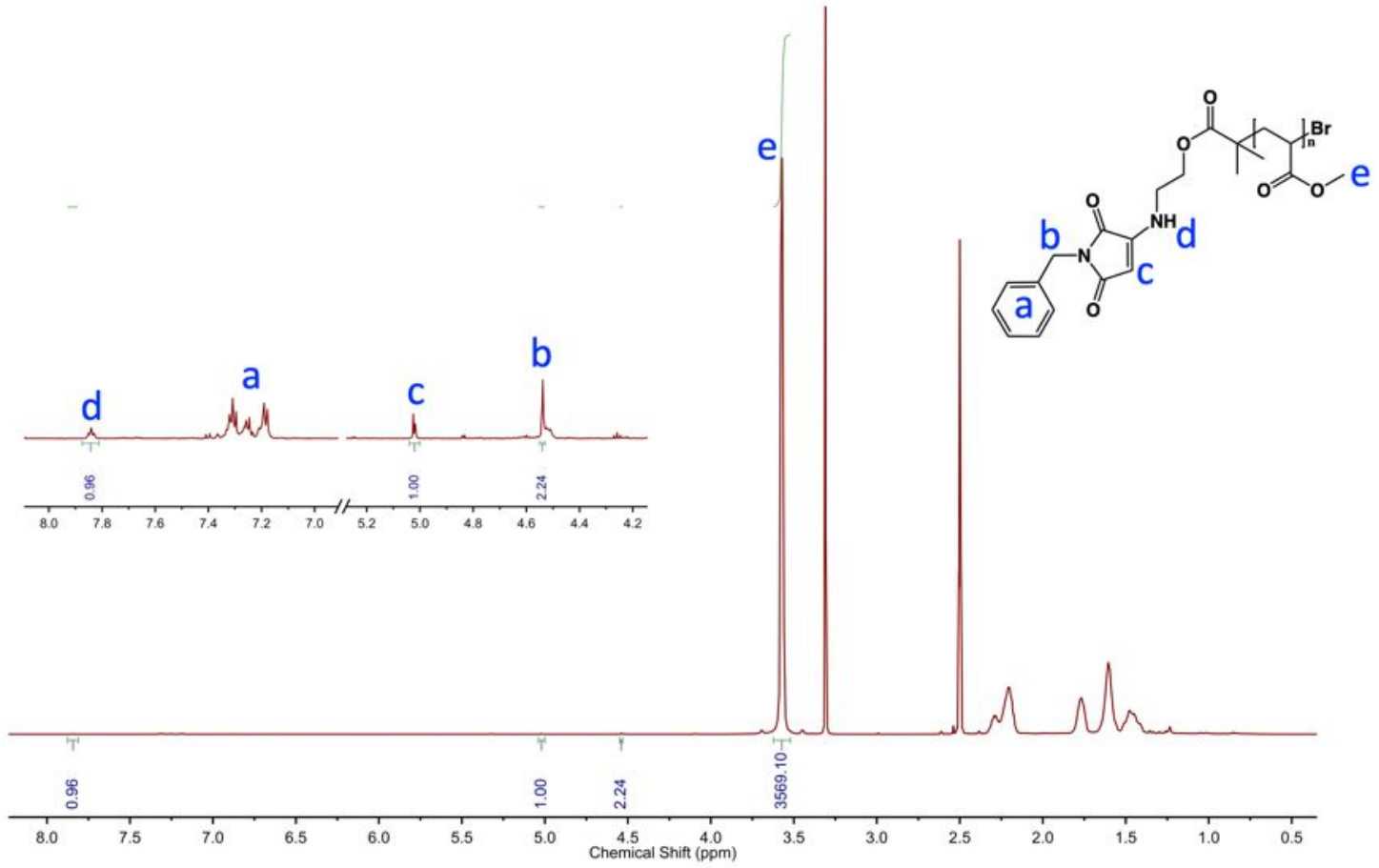

Figure S30. ${ }^{1} \mathrm{H}-\mathrm{NMR}$ spectrum of the reference polymer in DMSO-d6. 


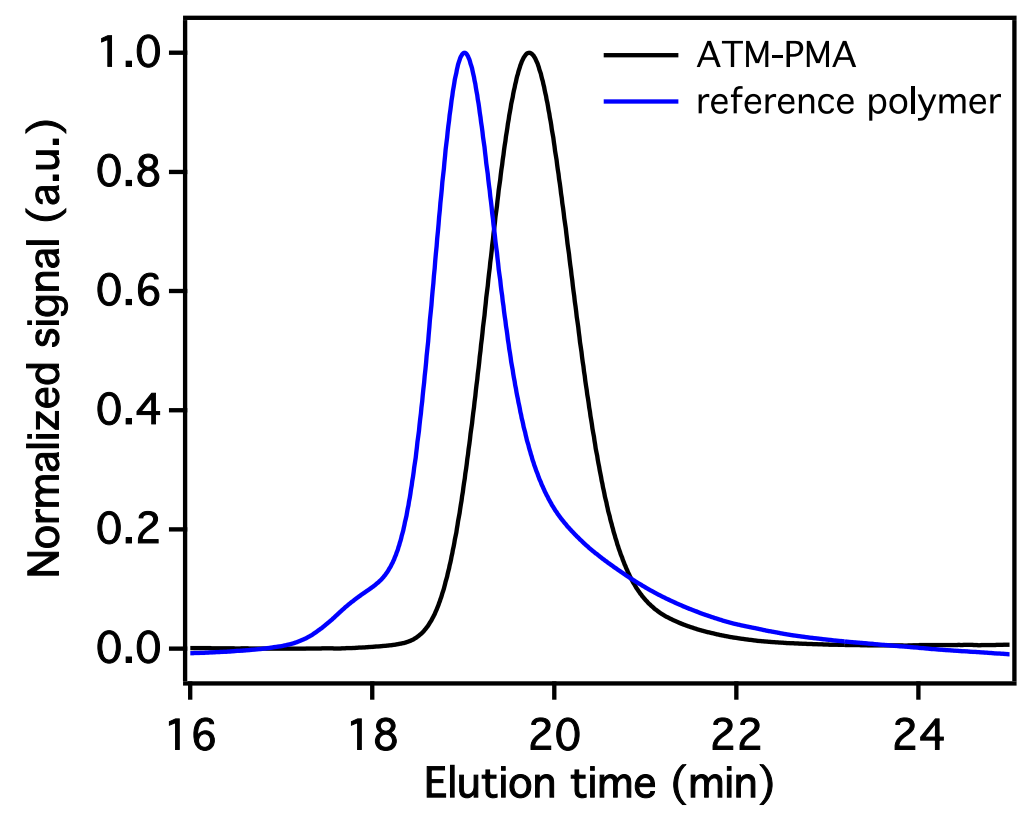

Figure S31. SEC traces of ATM-PMA and the reference polymer.

\section{References}

(1) Karman, M.; Verde-Sesto, E.; Weder, C.; Simon, Y. C., Mechanochemical Fluorescence Switching in Polymers Containing Dithiomaleimide Moieties. ACS Macro Lett. 2018, 7, 1099-1104.

(2) Beyer, M. K., The mechanical strength of a covalent bond calculated by density functional theory. J. Chem. Phys. 2000, 112, 7307-7312. 